\title{
Carsharing: a systematic literature review and research agenda
}

\author{
Brenda Nansubuga \\ Department of Management and Engineering, Linköping University, \\ Linköping, Sweden, and \\ Christian Kowalkowski \\ Department of Management and Engineering, Linköping University, \\ Linköping, Sweden and \\ Department of Marketing, \\ CERS - Centre for Relationship Marketing and Service Management, \\ Hanken School of Economics, Helsinki, Finland
}

Carsharing: a systematic literature review

Received 3 October 2020

Revised 12 April 2021

26 June 2021

Accepted 28 June 2021

\begin{abstract}
Purpose - Following the recent surge in research on carsharing, the paper synthesizes this growing literature to provide a comprehensive understanding of the current state of research and to identify directions for future work. Specifically, this study details implications for service theory and practice.

Design/methodology/approach - Systematic selection and analysis of 279 papers from the existing literature, published between 1996 and 2020.

Findings - The literature review identified four key themes: business models, drivers and barriers, customer behavior, and vehicle balancing.

Practical implications - For managers, the study illuminates the importance of collaboration among stakeholders within the automotive sector for purposes of widening their customer base and maximizing utilization and profits. For policy makers, their important role in supporting carsharing take-off is highlighted with emphasis on balancing support rendered to different mobility services to promote mutual success.

Originality/value - This is the first systematic multi-disciplinary literature review of carsharing. It integrates insights from transportation, environmental, and business studies, identifying gaps in the existing research and specifically suggesting implications for service research.
\end{abstract}

Keywords Carsharing, Nonownership, Vehicle balancing, Automotive, Business model, Access-based consumption

Paper type Research paper

\section{Introduction}

Environmental concerns and the specter of "peak car" - the idea that per capita distance traveled by an automobile will now fall, threatening the traditional mass-market car business - have prompted automotive manufacturers, service providers, NGOs, and policy makers worldwide to devise and offer a wide range of carsharing services. Carsharing refers to the temporary right to exclusive use of a car without the responsibilities of ownership, with payments linked to usage and/or subscription fees. Unlike traditional car rental and leasing,

(C) Brenda Nansubuga and Christian Kowalkowski. Published by Emerald Publishing Limited. This article is published under the Creative Commons Attribution (CC BY 4.0) licence. Anyone may reproduce, distribute, translate and create derivative works of this article (for both commercial and noncommercial purposes), subject to full attribution to the original publication and authors. The full terms of this licence may be seen at http://creativecommons.org/licences/by/4.0/legalcode

This research received financial support from the CarE-Service project (which received funding from the European Union's Horizon 2020 research and innovation programme under grant agreement No 776851), and the SE:Kond 2 LIFE project (2019-04463), which was funded by Sweden's innovation agency Vinnova.

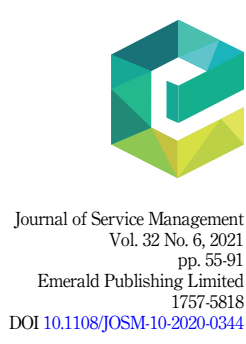


JOSM 32,6

carsharing relies on platform mediation to identify appropriate matches between provider resources and users and to facilitate exchange (Eckhardt et al., 2019). While car rentals require a contractual agreement each time one rents a car, carsharing typically requires a membership and subscription. Lovelock and Gummesson (2004) suggested that such nonownership services - that is, marketing exchanges, which do not involve a transfer of ownership - differ distinctly from those that do, conveying benefits through temporary access rather than ownership. By securing the temporary right to use a good, customers avoid "the burdens of ownership" (Moeller and Wittkowski, 2010), such as responsibility for maintenance and repair. Although accumulated service fees over time may be higher than the purchase price, individual payments are lower, making nonownership more affordable by comparison (Schaefers et al., 2018). Examples of carsharing include the pioneering Zipcar, which commenced operations in Massachusetts in 2000, and ShareNow, a collaboration between German automotive manufacturers BMW and Daimler. Achieving economic viability has proved challenging, and many projects are in retreat, for example, most of ShareNow's international operations have been closed down since 2019 (Miller, 2019). Nevertheless, industry and public research centers continue to invest heavily in new initiatives (Bocken et al., 2020), and many carsharing service providers see long-term market potential. In 2019, the global carsharing market exceeded US $\$ 2.5$ billion, with predicted growth of over $24 \%$ by 2026 (Global Growth Trends, 2021).

Mirroring these developments, research interest in carsharing has increased across diverse fields that include transportation, environmental and energy studies, and business and management. This research activity has yielded a wide array of analyses and is also an indicator that carsharing is seen to have wide-ranging implications for society. Research on carsharing also reflects the growing interest in various nonownership services (Schaefers et al., 2016a; Fritze et al., 2020). However, despite extensive attention from transportation and environmental researchers - as well as increasing popular interest and media coverage - few of these studies are grounded in service management research.

Against this backdrop, we conducted a systematic review to synthesize the growing literature on carsharing. The dramatic increase in publications in recent years highlights the need for such a review, with more than 60 scientific journal articles published in 2020 alone. The review had three aims: (1) to consolidate existing knowledge and to extract key insights across disciplines; (2) to identify implications for managers and policy makers; and (3) to outline an agenda for service research. The study addresses two main gaps in existing literature reviews. First, as most of these reviews focus on specific issues and fail to acknowledge the full array of relevant research themes, they are not directly comparable. Among these, Jorge and Correia's (2013) review focused specifically on vehicle relocation. Although Ferrero et al.'s (2018) review was (we believe) the first attempt to comprehend the existing carsharing literature, it was not systematic, and their search covered only papers on access-based carsharing published during the period 2001-2016. As more than 180 papers on carsharing have since been published, an updated review is needed to capture newer and more relevant insights on subjects such as peer-to-peer (P2P) carsharing. Furthermore, Ferrero et al.'s study focuses on transportation-related outlets and issues, so neglecting important service management and marketing-related issues. On that basis, the present study addresses the need for an exhaustive thematic review.

The rest of the paper is structured as follows: Section 2 describes the methodology for the systematic selection and analysis of relevant publications. Section 3 presents the study findings, which are grouped under four themes: business models, drivers and barriers, customer behavior, and vehicle balancing. Section 4 outlines a carsharing research agenda that addresses key questions and challenges for service providers and customers. In conclusion, Section 5 identifies some key implications for managers and policy makers. 


\section{Methodology}

The growing volume of fragmented research across disciplines makes it challenging to keep up with existing knowledge of carsharing, and a systematic literature review is needed to integrate findings and perspectives while minimizing bias (Snyder, 2019). A systematic review is an effective means of critically evaluating a body of literature in an objective, transparent, unbiased, and rigorous way (Boell and Cecez-Kecmanovic, 2015; Lyngdoh et al., 2021) and increases the validity of the review process (Palmatier et al., 2018). Following Tranfield et al. (2003), our approach involved three stages: planning, conducting and reporting the review.

\subsection{Planning and conducting the review}

In the first stage (planning), we assessed the need for a systematic review of the carsharing literature. In the second stage (conducting the review), we identified and selected relevant publications, using the specified keywords ("carsharing," "shared mobility," "mobility services" and "mobility-as-a-service") to search the Scopus database. As a leading database, Scopus is widely used for systematic reviews (e.g. Raddats et al., 2019; Witell et al., 2016). To ensure that the search was comprehensive, we used the Boolean operators "AND" and "OR" (Cronin et al., 2008). As keywords are the cornerstone of a systematic literature review (Timmins and McCabe, 2005), we selected terms that were contextually relevant and reflected the scope of the carsharing literature, excluding related but distinct terms like "ride sharing" or "ride hailing." Although terms like "shared mobility" and "mobility-as-a-service" tend to be broader in scope than carsharing, some such studies nevertheless relate to carsharing and are likely to provide relevant insights (e.g. Cohen and Kietzmann, 2014). More generic terms like "sharing economy" or "access-based services" were not included because a majority of these studies only refer to carsharing as an example among many other services rather than as the focal concern (e.g. Eckhardt et al., 2019; Fritze et al., 2020). Studies that discuss carsharing in detail, like Bardhi and Eckhardt (2012), appear in searches using the term "carsharing," but we deliberately excluded studies dealing with other nonownership services that do not involve shared car use, such as car leasing (e.g. Wittkowski et al., 2013).

The search covered peer-reviewed journal papers published in English up to the end of 2020. To ensure a comprehensive overview of the field, the search was not confined to particular subjects or journals (Snyder et al., 2016), yielding an initial total of 1,417 papers. To begin the exclusion process, we read the abstracts and eliminated 1,051 papers that we deemed to be beyond the scope of our review. Some of the excluded papers related to topics like carbon emissions, autonomous vehicles, electric vehicle ownership, ride hailing, and ride sharing. Some addressed topics like mobile networks or mobility aids for the visually impaired but did not focus on automotive mobility, and these were also eliminated at this stage, leaving 366 papers in total. In the second round of the review, we read the remaining papers in full to assess their quality and to extract relevant information. We excluded any publications whose content failed to meet the specified criteria, for example, shared mobility studies with a very limited discussion of carsharing, or papers that focused on other vehicle sharing systems like bike sharing. As a result, a further 87 papers were excluded, leaving a final sample of 279 papers (see Appendix for subject areas, journals by subject, and number of papers published in each journal). Figure 1 summarizes the search and selection process.

To begin the review stage, the lead author read and categorized each paper in relation to the research topic. The research team then discussed the results, paying particular attention to papers in which the dominant theme was less easily discerned. For example, although electric vehicle carsharing was originally identified as a distinct theme, it was subsequently assimilated to other themes because it was the focus of interest in only a limited number of papers. This iterative analysis yielded four major themes: (1) the wide variety of carsharing

Carsharing: a systematic literature review 


\section{JOSM}

32,6

Figure 1.

Literature search and selection process

\section{8}
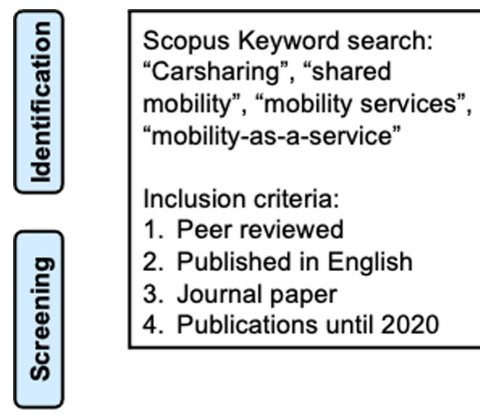

1. Peer reviewed

2. Published in English

3. Journal paper

4. Publications until 2020
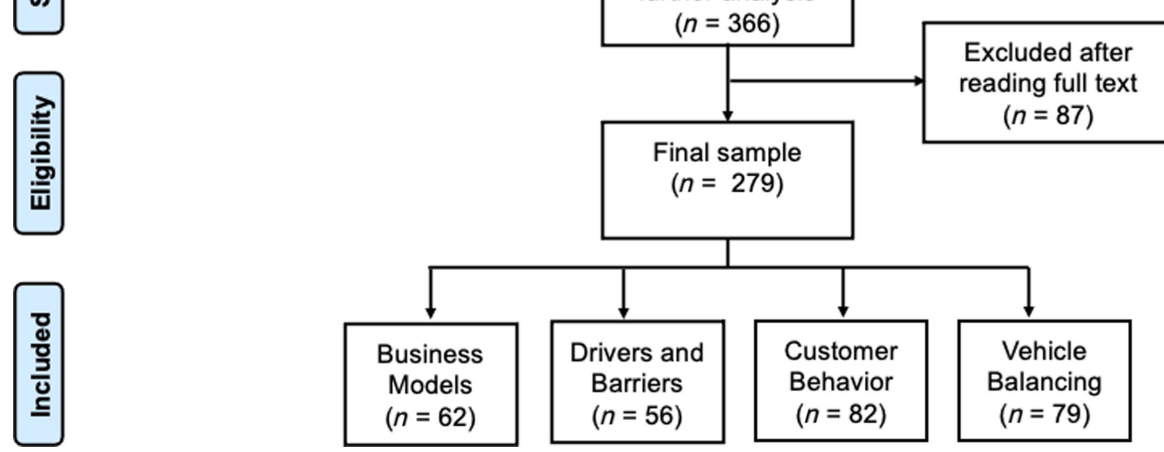

business models ( $n=62)$; (2) customer and service provider drivers and barriers $(n=56)$; (3) usage characteristics of carsharing customers, including behaviors and motives $(n=82)$; and (4) vehicle balancing, encompassing issues related to station location and vehicle relocation $(n=79)$. To assess the reliability of this categorization, another researcher independently reviewed the final sample of 279 papers. We assessed inter-judge reliability in terms of the proportional reduction in loss, which at 0.96 was well above the recommended 0.90 threshold for advanced practice (Rust and Cooil, 1994). In cases where the two researchers differed usually where a paper covered more than one theme - the research team jointly reviewed and discussed the study before agreeing a mutually acceptable categorization. Any additional relevant insights beyond a study's core theme are noted in the results.

\subsection{Descriptive analysis of the field}

Research on carsharing has grown rapidly, and the number of papers published in the last four years was more than double the total for all previous years combined. On average, less than two papers were published annually between 1996 (when the first paper appeared) and 2011. The topic began to attract greater research interest in 2012, when 15 papers were published, almost equaling the number of papers published in all previous years combined. Since then, the topic has attracted increasing research attention, and more than 60 papers were published in 2020 alone. Research initially focused on the nature of existing and potential business models for carsharing, customer reasons for engagement and customer behavior; over the years, interest has extended to key challenges like vehicle balancing. Table 1 shows the evolution of coverage of the four themes.

Overall, research on carsharing has most often appeared in transportation journals (125/ 279), with fewer (43/279) in business and management publications (including service and marketing) or environmental and energy journals (58/279) (see Appendix). However, the three most cited papers for each theme appear in business and management journals (four papers), transportation journals (six papers), and environmental and energy journals (two papers) (see 


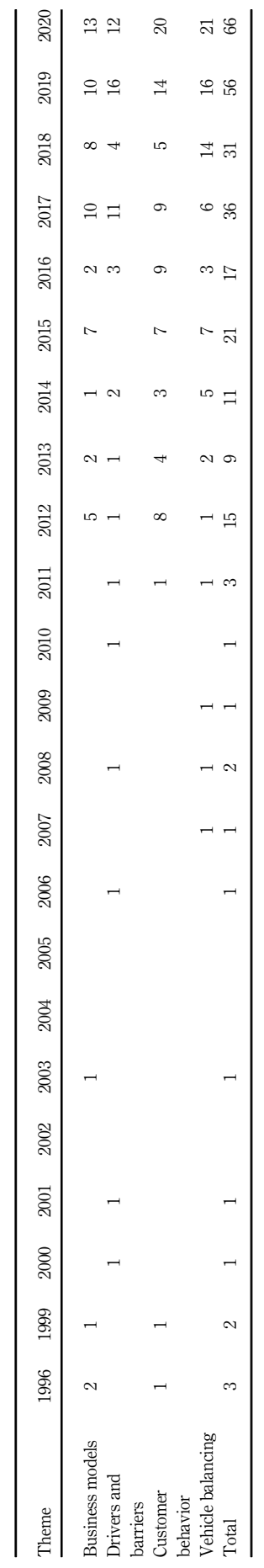

Carsharing: a systematic literature review

59

Table 1

Publications by topic and year 
JOSM

32,6

60

\begin{tabular}{|c|c|c|c|c|c|}
\hline Theme & Authors & Journal & Focus & Method & Citations \\
\hline \multirow[t]{3}{*}{$\begin{array}{l}\text { Business } \\
\text { models }\end{array}$} & $\begin{array}{l}\text { Bardhi and } \\
\text { Eckhardt } \\
\text { (2012) }\end{array}$ & $\begin{array}{l}\text { Journal of consumer } \\
\text { research }\end{array}$ & $\begin{array}{l}\text { Access-based } \\
\text { consumption }\end{array}$ & $\begin{array}{l}\text { Interviews } \\
n=40\end{array}$ & 883 \\
\hline & $\begin{array}{l}\text { Möhlmann } \\
(2015)\end{array}$ & $\begin{array}{l}\text { Journal of consumer } \\
\text { behavior }\end{array}$ & $\begin{array}{l}\text { Collaborative } \\
\text { consumption }\end{array}$ & $\begin{array}{l}\text { Two surveys } \\
(n=236,187)\end{array}$ & 563 \\
\hline & $\begin{array}{l}\text { Cohen and } \\
\text { Kietzmann } \\
\text { (2014) }\end{array}$ & $\begin{array}{l}\text { Organization and } \\
\text { environment }\end{array}$ & $\begin{array}{l}\text { Shared mobility } \\
\text { business models }\end{array}$ & Conceptual & 424 \\
\hline \multirow[t]{3}{*}{$\begin{array}{l}\text { Drivers } \\
\text { and } \\
\text { barriers }\end{array}$} & $\begin{array}{l}\text { Shaheen and } \\
\text { Cohen (2012) }\end{array}$ & $\begin{array}{l}\text { International journal } \\
\text { of sustainable } \\
\text { transportation }\end{array}$ & $\begin{array}{l}\text { Station-based } \\
\text { carsharing }\end{array}$ & $\begin{array}{l}\text { Three surveys: } \\
n=33,22,25\end{array}$ & 308 \\
\hline & $\begin{array}{l}\text { Prieto et al. } \\
\text { (2017) }\end{array}$ & $\begin{array}{l}\text { Transportation } \\
\text { research part A: } \\
\text { Policy and practice }\end{array}$ & $\begin{array}{l}\text { Impact of } \\
\text { sociodemographic } \\
\text { variables on } \\
\text { carsharing }\end{array}$ & $\begin{array}{l}\text { Survey } \\
n=2,733\end{array}$ & 87 \\
\hline & $\begin{array}{l}\text { Wilhelms } \\
\text { et al. (2017a) }\end{array}$ & $\begin{array}{l}\text { Technological } \\
\text { forecasting and social } \\
\text { change }\end{array}$ & P2P carsharing & $\begin{array}{l}\text { Interviews } \\
n=20\end{array}$ & 59 \\
\hline \multirow{3}{*}{$\begin{array}{l}\text { User } \\
\text { behavior }\end{array}$} & $\begin{array}{l}\text { Dijk et al. } \\
(2013)\end{array}$ & Energy policy & EV mobility & Conceptual & 178 \\
\hline & $\begin{array}{l}\text { Efthymiou } \\
\text { et al. (2013) }\end{array}$ & Transport policy & $\begin{array}{l}\text { Adoption of vehicle } \\
\text { sharing systems }\end{array}$ & Survey $n=233$ & 152 \\
\hline & $\begin{array}{l}\text { Schaefers } \\
\text { (2013) }\end{array}$ & $\begin{array}{l}\text { Transportation } \\
\text { research part A: } \\
\text { Policy and practice }\end{array}$ & $\begin{array}{l}\text { Consumer cognitive } \\
\text { processes }\end{array}$ & $\begin{array}{l}\text { Interviews } \\
n=14\end{array}$ & 132 \\
\hline \multirow[t]{3}{*}{$\begin{array}{l}\text { Vehicle } \\
\text { balancing }\end{array}$} & $\begin{array}{l}\text { Kek et al. } \\
(2009)\end{array}$ & $\begin{array}{l}\text { Transportation } \\
\text { research part E: } \\
\text { Logistics and } \\
\text { transportation review }\end{array}$ & $\begin{array}{l}\text { Optimal parameters } \\
\text { for vehicle relocation }\end{array}$ & $\begin{array}{l}\text { Simulation } \\
\text { modeling }\end{array}$ & 227 \\
\hline & $\begin{array}{l}\text { Correia and } \\
\text { Antunes } \\
\text { (2012) }\end{array}$ & $\begin{array}{l}\text { Transportation } \\
\text { research part E: } \\
\text { Logistics and } \\
\text { transportation review }\end{array}$ & $\begin{array}{l}\text { Station location in one- } \\
\text { way carsharing }\end{array}$ & $\begin{array}{l}\text { Mixed-integer } \\
\text { programming }\end{array}$ & 201 \\
\hline & $\begin{array}{l}\text { Boyaci et al. } \\
(2015)\end{array}$ & $\begin{array}{l}\text { European journal of } \\
\text { operational research }\end{array}$ & $\begin{array}{l}\text { Vehicle relocation in } \\
\text { one-way EV sharing }\end{array}$ & $\begin{array}{l}\text { Location } \\
\text { modeling }\end{array}$ & 196 \\
\hline
\end{tabular}

Table 2). While citation analysis is biased toward older publications, it is a useful way of identifying the main work in a given field (Raddats et al., 2019; Zupic and Cater, 2015). It is interesting that while the majority of papers were published in transportation journals, the two most cited papers were consumer studies that appeared in business and management publications. It is also notable that despite the growing importance for service and marketing researchers of concepts like the sharing economy and collaborative consumption (e.g. Eckhardt et al., 2019; Guyader, 2018), few such studies have specifically investigated carsharing. As discussed below, it therefore seems useful to develop a fuller account of user needs and the challenges faced by carsharing service providers from the perspective of service management.

\section{Results}

This section discusses the four themes elaborated in the third review stage (reporting and dissemination) (Tranfield et al., 2003). To begin, the evolution of carsharing is briefly summarized. 


\subsection{Evolution of carsharing}

The concept of carsharing can be traced back to 1948 in Zurich, Switzerland, when the earliest known carsharing cooperative was formed by a group of private individuals. This initiative was followed soon after by similar ventures in other European countries, including France and the Netherlands (Shaheen et al., 1998). Early carsharing schemes operated on a round-trip basis, in which the customer returned the car to its original pick-up location at the end of each rent period. The earliest known one-way carsharing scheme (known as Procotip) was established in France in 1971, but it failed as a result of technological issues and a lack of appropriate control systems (Shaheen et al., 2015). Despite these early efforts, successful cases of carsharing were not identified until the late 1980 and 1990s, when various carsharing cooperatives in Switzerland (e.g. Mobility) were established. In 2008, Daimler formed the first free-floating carsharing scheme (then called Car2go and now known as ShareNow) in Ulm, Germany (Firnkorn and Müller, 2012).

As concern grew about traffic congestion caused by increased car ownership (Steininger et al., 1996), carsharing was seen to offer multiple benefits to users, governments and service providers (Tuan Seik, 2000). Beyond its initial appeal to environmentalists and community activists, today's users are motivated by factors like personal convenience and cost savings (Orski, 2001). Other reported reasons for adopting carsharing include time savings, traffic mitigation, and individual attitudes (Fellows and Pitfield, 2000). Shaheen et al. (1999) predicted that carsharing providers might combine their operational expertise with other advanced technology suppliers to offer mobility services with social, economic and environmental benefits. In many respects, this is true of carsharing today, which has been transformed by advances such as P2P services and technologies, growing stakeholder cooperation and integration, new automotive ventures, and a renewed emphasis on electric vehicles (EVs).

\subsection{Carsharing business models}

A business model describes how a business creates and captures value, articulating the value proposition, resources, and associated costs and revenue mechanisms (Teece, 2010). Among carsharing services providers, business models vary widely from access-based services such as business-to-consumer (B2C) and business-to-business (B2B) models and cooperatives to platform-based peer-to-peer (P2P) models.

Most carsharing business models fall into the category of access-based services (Bardhi and Eckhardt, 2012), which allow customers to access a product for a specified period in return for an access payment while the service provider retains legal ownership (Schaefers et al., 2016b). Access-based services are considered suitable for convenience-seeking customers who do not care about the value of ownership and favor monetary savings (Hazée et al., 2017). According to Hazée et al. (2017), such services entail a high level of customer involvement, minimal supervision by the service provider and high levels of interpersonal anonymity, as customers have minimal contact with other customers or employees when accessing the products.

3.2.1 Business-to-consumer carsharing. As the most common type of carsharing, B2C models have so far received the most research attention. This form of carsharing entails ownership of a fleet of cars by a firm, which rents them on demand to private individuals for short periods of time (Münzel et al., 2018). In addition to these independent service providers, car manufacturers also engage in B2C carsharing in their search for new markets (Bellos et al., 2017; Perboli et al., 2018). As the owner (or lessee), the service provider assumes responsibility for car maintenance and marketing transactions (Wilhelms et al., 2017a). B2C carsharing is generally usage-based, that is, members pay a service provider for access to cars at a given rate based on minutes or hours, or at a daily rate for distance traveled (Schmöller et al., 2015). Different membership types are often available - for example, pay-per-use or monthly subscription - according to the customer's expected level of usage (Bocken et al., 2020). B2C carsharing may be one-way or round-trip (in which the car is returned to the pick-up location
Carsharing: a systematic literature review 
JOSM 32,6

62

after use) (Cohen and Kietzmann, 2014; Le Vine et al., 2014). Additionally, membership may be station-based or free-floating; in the former case, the customer must leave the car at a designated station within a given area, while a free-floating arrangement means they can leave the car at any location within the designated area (Shaheen et al., 2015). Users of freefloating and station-based services typically use the cars for short trips while round-trip customers mostly take longer trips (Alencar et al., 2019). Use of free-floating or station-based carsharing also varies according to trip length and purpose (Heilig et al., 2018); while stationbased carsharing is favored mainly when a car is the most effective solution, the free-floating option is often preferred for nonregular trips (Becker et al., 2018) and saves time as compared to alternatives like public transport (Becker et al., 2017a). Examples of B2C carsharing include Zipcar (founded in 2000 and acquired by Avis Budget Group in 2013) and ShareNow, a joint venture involving the German manufacturers BMW and Daimler.

3.2.2 Business-to-business carsharing. B2B carsharing - also referred to as corporate carsharing or employer-based carsharing (Clark et al., 2015) - is an option for organizations that do not wish to own or lease a fleet. Using this form of carsharing, employers provide access through a service provider to shared cars for employees' work-related trips (Fleury et al., 2017). B2B carsharing customers may be private or public sector organizations (Clark et al., 2015). B2B carsharing is usually offered by B2C service providers (e.g. ShareNow and Volvo Car's M), and the two models are broadly similar, aside from the fact that the $\mathrm{B} 2 \mathrm{~B}$ customers are organizations, and subscriptions or payments are made by the organization rather than the individual user. Typically, an employer signs a contract with the provider that specifies fees and terms of payment for the service. Potential customer benefits include lower travel costs as compared to car rental or taxis, as well as flexible fleet size, customized services and price models, and consolidated invoicing. For larger customers especially, service providers must have the necessary resources to provide personal support (e.g. through key account managers) and to ensure that the value potential is realized. Although one study of carsharing behavior in Toronto reported that B2B customers use carsharing more frequently than B2C customers (Costain et al., 2012), B2B carsharing has so far received much less research attention.

3.2.3 Cooperative carsharing. A third type of access-based carsharing business model is also known as the nonprofit car club (Bonsall et al., 2002) or self-regulating community (Hofmann et al., 2017), based on collective car ownership and usage within a defined or institutionalized local group such as friends, neighbors or a nonprofit organization (Nitschke, 2020). This model is typically characterized by a communal interest in sharing cars rather than any profit motive (Cohen and Kietzmann, 2014; Münzel et al., 2018). Members of cooperative carsharing schemes usually pay an annual membership deposit or monthly mileage fees, with contractual obligations governing car maintenance and other administrative responsibilities (Bocken et al., 2020). As nonprofit organizations, cooperative carsharing schemes can often secure funding from government agencies and foundations. As they are usually community-based, these schemes tend to be small in size, favor a round-trip approach and offer only limited choices of car. One example of cooperative carsharing is the member-owned Modo, which was founded in 1997 in Vancouver, Canada.

3.2.4 Peer-to-peer carsharing. P2P carsharing business models can be classified under the broader term collaborative consumption, which is defined as the use of online marketplaces and social networking technologies to facilitate peer-to-peer resource sharing (Barnes and Mattsson, 2016; Hamari et al., 2016). P2P carsharing involves a triadic relationship between a car owner, a platform provider and a car renter (the customer) (Wilhelms et al., 2017a). For the car owner, this involves renting out one's personal car and collecting the agreed monetary compensation (Barbour et al., 2020); for the customer, it entails renting a car from a private individual through an online platform (Meelen et al., 2019). As the platform provider does not own any cars, its role in P2P carsharing is to act as an intermediary between the car owner 
and customer (Meelen et al., 2019; Münzel et al., 2018). P2P carsharing customers often pay a fee per use, and the platform provider takes a percentage of the rental fee paid by the customer. Under the P2P arrangement, the car owner assumes responsibility for maintaining and cleaning the car (Hartl et al., 2018) and determines the rental duration (Bocken et al., 2020). As P2P platform providers do not incur fleet investment costs, this form of carsharing has higher scalability potential than the access-based model (Hampshire and Gaites, 2011; Meelen et al., 2019).

While sharing of goods between individuals has always existed, the idea of P2P carsharing as a business is quite a recent development. Despite its growing popularity, this model has not received much research attention to date, and most studies focus on customer motivations (e.g. Barbour et al., 2020; Dill et al., 2019; Wilhelms et al., 2017b). Examples of P2P carsharing platforms include Getaround, which operates in the US and in some European markets (including France and the UK) and Turo, which operates in the US, Canada and the UK.

3.2.5 Business model typology. Based on the work of Hahn et al. (2020) and Wilhelms et al. (2017b), Table 3 outlines the main characteristics of each business model. There are several differences between carsharing business models beyond value proposition, resources and revenue mechanism. Pricing is one of the most important factors, as it plays a role in determining the customer type and level of usage (Balac et al., 2017). Various strategies have been devised to make carsharing profitable, including dynamic pricing schemes based on availability and time (Giorgione et al., 2020); for a company targeting a younger clientele, for example, the ideal pricing model combines usage-based and monthly fees (Hahn et al., 2020). In the early phase of $\mathrm{P} 2 \mathrm{P}$ carsharing, there were several experiments in the absence of an established pricing model; for instance, some operators allowed car owners to specify their own rental prices while others allowed the platform provider to set the price (Barbour et al., 2020).

Both P2P and cooperative carsharing have a cost advantage over B2C and B2B. As cooperative schemes are not profit-driven, and P2P car owners usually only want to earn some additional income from their cars, rental prices are usually lower than those of B2C and B2B providers, who need to make a profit on their investment (Hofmann et al., 2017; Münzel et al., 2018). A second difference relates to fleet size; while cooperative schemes often have only a few cars, $\mathrm{B} 2 \mathrm{C}$ and $\mathrm{B} 2 \mathrm{~B}$ providers range from hundreds to more than a thousand cars (depending on the city size), or indeed several thousand in the case of P2P (Münzel et al., 2018). In terms of required investment, this means that both $\mathrm{B} 2 \mathrm{~B}$ and $\mathrm{B} 2 \mathrm{C}$ carsharing providers need significantly more capital than cooperative or P2P schemes. Additionally, as P2P cars are owned by individuals, the level of service provided may vary from one individual car owner to another.

3.2.6 Digital technologies. Digital technologies have had a major impact on the development of carsharing business models, especially P2P. Lagadic et al. (2019) observed that while carsharing is not a new service type, it has been completely transformed by advances in digital technologies. Although access-based services derive from traditional marketplace rental models, they have evolved through digital technology into a more collaborative and self-service approach (Bardhi and Eckhardt, 2012). Similarly, the growth of carsharing has been aided by advances such as mobile apps, global positioning system (GPS), software that monitors fuel and battery usage, open-ended booking and smart locks that allow instant access (Alfian et al., 2015; Münzel et al., 2018). In B2B carsharing setups, online dashboards can offer customers a consolidated overview of all user activities.

While technology plays an integral role in all types of carsharing, P2P carsharing relies more than other business models on technological innovations (Julsrud and Farstad, 2020). In particular, P2P carsharing must make booking and key exchange as convenient as possible (Sprei and Ginnebaugh, 2018), and this has become easier with smart locks that allow renters to access a car without having to meet the owner (Münzel et al., 2018). The increased
Carsharing: a systematic literature review 
JOSM

\begin{tabular}{l}
32,6 \\
$\mathbf{6 4}$ \\
\hline
\end{tabular}

\begin{tabular}{l}
$\begin{array}{l}\text { Business } \\
\text { model }\end{array}$ \\
\hline Examples \\
Value \\
proposition
\end{tabular}

Key resources

Car fleet, fleet management, service network, usage and user behavior data

\begin{tabular}{|c|c|}
\hline $\begin{array}{l}\text { Revenue } \\
\text { mechanism }\end{array}$ & $\begin{array}{l}\text { Monthly } \\
\text { subscription or } \\
\text { pay-per-use }\end{array}$ \\
\hline $\begin{array}{l}\text { Market } \\
\text { mediation }\end{array}$ & Commercial \\
\hline Car ownership & $\begin{array}{l}\text { Carsharing } \\
\text { company }\end{array}$ \\
\hline $\begin{array}{l}\text { Investment } \\
\text { requirement by } \\
\text { the provider }\end{array}$ & High \\
\hline $\begin{array}{l}\text { Pick-up and } \\
\text { drop-off mode }\end{array}$ & $\begin{array}{l}\text { One-way or round- } \\
\text { trip }\end{array}$ \\
\hline Involved actors & $\begin{array}{l}\text { Carsharing } \\
\text { company, } \\
\text { customers }\end{array}$ \\
\hline $\begin{array}{l}\text { Business model } \\
\text { innovator }\end{array}$ & $\begin{array}{l}\text { Carsharing } \\
\text { company }\end{array}$ \\
\hline Fleet variety & Low-medium \\
\hline $\begin{array}{l}\text { Geographical } \\
\text { coverage }\end{array}$ & $\begin{array}{l}\text { Limited to busy } \\
\text { areas }\end{array}$ \\
\hline Car & Carsharing \\
\hline $\begin{array}{l}\text { maintenance } \\
\text { and cleaning }\end{array}$ & company \\
\hline
\end{tabular}

Platform-based models P2P

Getaround, Turo mobility (M) Provides organizations with access to cars for work-related trips without the burdens of fleet ownership; offers consolidation of fleet management activities

Car fleet, fleet management, service network, account management, contracting, usage and user behavior data Contract-based

Commercial

Carsharing company

High

Annual membership or monthly fee

Car fleet, members' network

Provides communities with access to cars without the burdens of individual ownership

Not-for-profit

Joint ownership by members

Moderate

Provides individuals with access to privately owned cars at lower prices than alternative traditional $\mathrm{B} 2 \mathrm{C}$ carsharing. Participating car owners can defray some of the ownership costs and monetize an idle asset

IT platform, insurance and assistance coverage, car owner, usage, and user behavior data, wide variety of cars in the network Pay-per-use

Commercial

Private individuals

Low

One-way or roundtrip

Carsharing Cooperative company, employer organization and employees

Carsharing company

Low-medium

Limited to busy areas association, car renters

Cooperative members

Low

Selected

geographical areas (often neighborhood scale)

Carsharing company

Contractual

Round-trip

Car owners, platform providers, customers

Platform provider

High

Wide coverage

Private car owner obligations

Table 3.

Carsharing business models

Source(s): Adapted from Wilhelms et al. (2017) and Hahn et al. (2020) 
incorporation of technology into carsharing services enhances the value proposition for the customer by making the service more flexible and convenient (Lagadic et al., 2019). As noted above, from a service research perspective, P2P carsharing differs from other carsharing models by virtue of its triadic structure. While many of the factors discussed here are relevant to all business models, most studies of carsharing explicitly or implicitly refer to B2C models or to access-based models in general. For that reason, it is important to highlight the differences between $\mathrm{B} 2 \mathrm{C}$ and $\mathrm{P} 2 \mathrm{P}$ models, especially with regard to customer behavior drivers and barriers.

\subsection{Drivers and barriers}

Individuals and business customers increasingly choose to rent objects for specific periods of time as needed rather than owning them; Lovelock and Gummesson (2004) refer to this as the rental/access paradigm. This is explained by Moeller and Wittkowski (2010) in terms of what they refer to as the burdens of ownership; that is, product ownership entails certain burdens that users may prefer to avoid, such as risks related to product updates and obsolescence, responsibility for product maintenance and repair, and incurring the full cost of the product. In the same way, carsharing customers are driven by a desire to avoid the burdens of car ownership. Carsharing has multiple benefits as an affordable mobility alternative for lowerincome groups like students and seniors, and as a substitute for transport alternatives such as walking and biking (Cohen et al., 2008). Most studies of the decision to use carsharing relate to $\mathrm{B} 2 \mathrm{C}$ business models, and some recent studies have specifically discussed the issue in the context of B2B or communal carsharing, but few studies to date have dealt specifically with drivers and barriers in relation to $\mathrm{P} 2 \mathrm{P}$ carsharing.

3.3.1 Key factors driving the demand and use of carsharing. Multiple studies have found that propensity to adopt carsharing in general is commonly influenced by sociodemographic, geographic and socioeconomic factors (e.g. Cartenì et al., 2016; Coll et al., 2014; Kang et al., 2016). Other factors include convenience (Orski, 2001; Peterson and Simkins, 2019), mobility patterns, family decisions, cost, and quality of alternative transport modes, lifestyle, and customer segment (Chun et al., 2019; Hahn et al., 2020).

Sociodemographic factors like age and gender are often mentioned as influencing factors for adoption of carsharing (e.g. Carteni et al., 2016; Juschten et al., 2019; Shaheen and Martin, 2010). Some studies report that the average carsharing customer is young, male, middle class, more highly educated and from a household of below-average size (e.g. Becker et al., 2017a; Clewlow, 2016; De Luca and Di Pace, 2015; Hjorteset and Böcker, 2020; Tyndall, 2017). In a web-based study of vehicle availability in ten different European cities, Boldrini et al. (2019) found a positive correlation between carsharing demand and sociodemographic and urban indicators such as high educational attainment. In a survey of women's carsharing usage, del Mar Alonso-Almeida (2019) attributed the predominance of male carsharing customers to the fact that the mobile technology platforms on which carsharing services are based are less appealing to women than to men. Similarly, the predominance of younger carsharing customers can be attributed to their greater familiarity with technological devices like smartphones (Burlando et al., 2019; Guglielmetti Mugion et al., 2019).

Geographically, carsharing demand is higher in urban centers than in rural areas (Prieto et al., 2017); this can be attributed to factors that make car ownership difficult and more expensive in urban centers, such as limited parking space. Carsharing adoption is positively affected by availability of other transport modes and scarcity of parking space (Csonka and Csiszar, 2016: Juschten et al., 2019; Münzel et al., 2020). In addition, close proximity to a carsharing station or to available cars increases the probability that individuals will use carsharing (Diana and Ceccato, 2019; Jian et al., 2016; Juschten et al., 2019; Kent et al., 2017; Zhou and Kockelman, 2011). A survey in Beijing by Shaheen and Martin (2010) established
Carsharing: a systematic literature review 
JOSM 32,6 that one kilometer is the maximum distance that users are willing to walk to a carsharing station.

Regarding socioeconomic factors, the claim that carsharing is valued for its ability to provide cost savings for customers (Duncan, 2011; Orski, 2001) is contradicted by Hjorteset and Böcker (2020). In their investigation of propensity to adopt carsharing in Norway, they showed that carsharing appeals mainly to individuals who are unconcerned about reducing their expenditure, indicating that the choice is not motivated by cost reduction. Similarly, in a study of carsharing in Switzerland, Juschten et al. (2019) reported that high income increases the probability of adopting carsharing. However, Hjorteset and Böcker (2020) did not distinguish between $\mathrm{P} 2 \mathrm{P}$ and $\mathrm{B} 2 \mathrm{C}$ customers, and results may vary by carsharing type. While carsharing in the developed economies of Europe and North America is used predominantly by highly educated individuals (Boldrini et al., 2019; Clewlow, 2016; Coll et al., 2014; Hjorteset and Böcker, 2020; Münzel et al., 2020), Chun et al. (2019) reported that the opposite is true for developing economies, where highly educated individuals are more likely to favor car ownership.

Studies of the drivers of carsharing indicate a clear relationship between carsharing and urban population density (e.g. de Lorimier and El-Geneidy, 2013; Cohen et al., 2008; Coll et al., 2014; Csonka and Csiszar, 2016). For example, Becker et al. (2017b) found that free-floating carsharing in Switzerland scales with population density and social activity in a given area. As it is also more prevalent in areas with low car ownership and public transport, they concluded that carsharing serves as an alternative to these transport modes. Similarly, in their analysis of factors that favor carsharing, Coll et al. (2014) identified urban sprawl and a fairly good public transport system as drivers of carsharing.

Carsharing is often linked to general environmental benefits such as reduction of greenhouse gas emissions (Cohen et al., 2008; Fleury et al., 2017). According to a study investigating choice of transport mode under uncertainty (Kim et al., 2017a), improving the symbolic value of carsharing as an environmentally friendly solution by use of EVs makes it a more attractive option and increases market share. Carsharing is perceived as more environmentally friendly than private car ownership (Münzel et al., 2020) but less environmentally friendly than public transport (Kim et al., 2017a). However, in a study of EV carsharing in Germany, Schwabe (2020) found that customer adoption of carsharing depends on more than perceived environmental friendliness. A study based on in-depth interviews with carsharing users in Norway (Julsrud and Farstad, 2020) reported similar findings in relation to cooperative carsharing, revealing that in addition to environmental benefits, customers chose cooperative carsharing for its practical benefits, such as the convenience of access to a car. In short, as with carsharing in general, environmental consciousness may be one key driver but is insufficient alone.

Factors affecting demand may also depend on the type of carsharing. For example, if B2B corporate customers are to adopt carsharing, providers must meet high expectations in terms of flexibility and service quality (Loose et al., 2006). Fleury et al.'s (2017) survey of intention to use B2B carsharing in France indicates that motivating factors - especially for first time users - include tutorial videos, training and ease of access to the service provider. Probability of adoption is further increased if the service provided is perceived as environmentally friendly, which resonates with the growing emphasis on embedding sustainability goals in corporate strategies.

While most existing studies focus on access-based services (especially B2C), the factors that affect demand for P2P carsharing may differ for access-based carsharing models. In a study of five European cities, Münzel et al. (2020) reported that, in contrast to B2C, demand for $\mathrm{P} 2 \mathrm{P}$ carsharing was not affected by population density. For car owners and service providers, the greater scalability of $\mathrm{P} 2 \mathrm{P}$ overcomes the geographic limitations of $\mathrm{B} 2 \mathrm{C}$ carsharing as it is not dependent on population density (Dill et al., 2019). 
3.3.2 Key barriers to carsharing demand and use. The success of carsharing depends on making it more attractive to potential customers by overcoming perceived barriers (Kim et al., 2017b). While previous research focused on the burden of ownership (e.g. Moeller and Wittkowski, 2010), Hazée et al. (2017) and Valor (2020) discuss the burdens of access and sharing, respectively. Hazée et al. (2017) classified the burdens of access in terms of functional and psychological barriers. Functional barriers included service complexity, which is associated with perceived access, usage, and understanding, and reliability, which refers to uncertainty about product performance and related technology. Psychological barriers included perceived contamination, referring to the fact that the product is also accessed and used by other (unknown) individuals, and responsibility, referring to customer concerns about being held accountable for their own and others' usage of available services.

These barriers also affect carsharing. In an early study, Shaheen et al. (1998) identified the limited availability of cars as one factor that limited the use of carsharing in residential areas. This finding relates to the issues of complexity and reliability identified by Hazée et al. (2017) as difficulty in accessing carsharing services when required undermines reliability and so acts as a barrier to adoption and use. Using a two-phase online survey, Kim et al. (2017a) confirmed that likelihood of carsharing use diminishes as waiting time increases. In the case of access-based services, cars must therefore be strategically located to service a wider pool of customers (Kim et al., 2019). In their study of Communauto in Montreal, Canada, de Lorimier and El-Geneidy's (2013) multilevel regression analysis showed that an efficient carsharing system must constantly attract new customers to compensate for lower use among seasoned members. To ensure customer satisfaction, the ideal situation combines high car availability and high car usage.

Low public awareness was identified by Zhou et al. (2017) as another significant obstacle to carsharing adoption in their survey of projected carsharing in Australia, Indonesia, Malaysia and Thailand. This problem relates to the compatibility barrier, where unfamiliarity can be a limiting factor. For example, lack of prior experience of similar services (such as car rental) is likely to deter certain potential customer groups from using carsharing. Both Duan et al. (2020), who used a stated preference survey to quantify the impacts of potential carsharing demands in Shanghai, and Zhang and Li (2020), who tested a model based on the theory of planned behavior in a study involving university students in Qingdao, China, reported that individuals who are familiar with car rental programs are more inclined to use carsharing.

In addition, nonmonetary costs (such as the inconvenience of having to reserve a car each time it is needed) may act as a barrier to carsharing (Duncan, 2011). In a survey to understand the factors that influence carsharing adoption, Burlando et al. (2019) found that issues like comfort and independence, which are often associated with private car ownership, may discourage carsharing adoption. Table 4 summarizes the main customer drivers and barriers identified in the literature.

3.3.3 Drivers and barriers for service providers and car owners. While much of the research on carsharing drivers and barriers has focused on the customer (especially in relation to B2C carsharing), only a handful of studies have discussed the service provider perspective. Service providers offer carsharing services for different reasons. Among profit-driven ventures, pure $\mathrm{B} 2 \mathrm{C}$ and $\mathrm{B} 2 \mathrm{~B}$ service providers are motivated mainly by the desire to make a profit on their services, while car manufacturers offer carsharing services mainly to expand their market and to explore untapped niches (Bellos et al., 2017; Perboli et al., 2018). On the other hand, in a study of 235 car owners in Portland, Oregon, who rented out their cars for P2P carsharing, Dill et al. (2019) found that they were motivated by the prospect of generating extra income, low levels of car use and willingness to help others. Even if not in financial need, car owners in P2P carsharing schemes may be motivated by a desire to maximize car
Carsharing: a systematic literature review 
JOSM 32,6

\section{8}

$\begin{array}{lll}\text { Factors } & \text { Key studies } & \text { Key points }\end{array}$

\section{Drivers}

Sociodemographic Becker et al. (2017a), Burlando et al. (2019), Cartenì et al. (2016), De Luca and Di Pace (2015), Guglielmetti Mugion et al. (2019), Hjorteset and Böcker (2020), Prieto et al. (2017), Shaheen and Martin (2010), Tran et al. (2019), Tyndall (2017)

Geographic

Csonka and Csiszar (2016), Diana and Ceccato (2019), Jian et al. (2016), Juschten et al. (2019), Kent et al. (2017), Kim et al. (2017b), Münzel et al. (2020), Zhou and Kockelman (2011)

Socioeconomic Boldrini et al. (2019), Hjorteset and Böcker (2020), Clewlow (2016), Coll et al. (2014), Chun et al. (2019), Münzel et al. (2020)

Population density $\quad$ Becker et al. (2017b), Cohen et al. (2008), Coll et al. (2014), de Lorimier and ElGeneidy (2013)

Environmental Kim et al. (2017a), Münzel et al. (2020), benefits Julsrud and Farstad (2020)

High service quality Fleury et al. (2017)

Barriers

Limited availability

Shaheen et al. (1998), Kim et al. (2017a), Kim et al. (2019), de Lorimier and ElGeneidy (2013)

Low public Burlando et al. (2019), Duncan (2011), awareness Zhang and Li (2020), Zhou et al. (2017)

Burdens of sharing Valor (2020)

\section{Table 4.}

Key customer drivers and barriers identified in the literature

\begin{abstract}
Higher demand among single-person households, especially males in their 20 s and 30 s and city center residents Customers are predominantly young, male, middle class, more highly educated and from a household of below-average size

Customers who opt for carsharing are encouraged by car availability, reliability and parking conditions
\end{abstract}

Higher education levels, moderate upper income levels

Carsharing scales with population density and social activity in a given area

Environmental benefits are important but are not the sole driver of carsharing service use

Customers, especially B2B, are attracted by high-quality services such as fleet management, tutorials and ability to access help

Likelihood of using carsharing services is reduced by increased waiting time for a shared car

Customers that have not previously used carsharing or similar services such as car renting are less likely to join a carsharing scheme

Customers and car owners in P2P carsharing experience burdens related to sharing, especially insecurity and uncertainty regarding contractual conditions

utilization or to make use of an otherwise underutilized asset (Ballús-Armet et al., 2014; Barbour et al., 2020; Dill et al., 2019). The claim that public awareness drives engagement in carsharing is further supported by the evidence that car owners who are familiar with the concept are more likely to offer their cars for P2P carsharing than those who are not (Münzel et al., 2019).

In addition to the high levels of investment required to engage in $\mathrm{B} 2 \mathrm{C}$ and $\mathrm{B} 2 \mathrm{~B}$ carsharing, operational hurdles such as vehicle balancing (especially in one-way schemes, as discussed in detail in section 3.5) present serious challenges for service providers. While many of the barriers that affect platform-based services have also been identified in studies of accessbased services, P2P carsharing must overcome some specific additional hurdles. P2P platform providers often face the double challenge of attracting both car owners and 
customers (Wilhelms et al., 2017b). Based on 20 in-depth interviews with early adopters in Spain, Valor (2020) identified burdens for car owners that included emotional costs associated with the difficulties of sharing, the possibility of damage and perceived physical insecurity when driving the returned car. For customers, burdens included anticipated friction with owners, uncertainty about contractual conditions, limited reliability and availability, and perceived insecurity when driving a P2P-rented car.

Access-related barriers for $\mathrm{P} 2 \mathrm{P}$ car owners include the perceived risk of limited access to their car (Hazée et al., 2020) and possible damage to the car while rented out. In a study of P2P carsharing in California, Ballús et al. (2014) noted that where the platform provider's package did not include insurance, fewer owners were willing to offer their car, as they would incur higher costs in the event of it being damaged. Hazée et al. (2020) discuss the image barrier as a common feature of collaborative consumption. As users are required to evaluate each other, car owners who worry that P2P carsharing may affect their standing in subsequent service requests may decide to withdraw.

\subsection{Customer behavior}

This theme relates to the travel behavior of carsharing customers, including specific customer traits and how they use carsharing services.

3.4.1 Usage characteristics of carsharing customers. Depending on the type of customer, carsharing services are used in different ways. In the case of B2C services, private individuals typically use carsharing for leisure travel and shopping (Sioui et al., 2012), while organizations use B2B carsharing for employees' work-related trips (Clark et al., 2015). In terms of demand, it may prove worthwhile to attract both private individuals and organizations as two customer groups that complement each other because they use cars at different times. In other words, private individuals might use the service for evening and weekend errands and leisure activities (Costain et al., 2012; de Lorimier and El-Geneidy, 2013), while organizations are likely to use the service during weekday working hours, so maximizing car utilization (Loose et al., 2006).

Charoniti (2020) investigated stated preferences for carsharing under uncertain travel times and noted that use of carsharing is strongly dependent on activity type and context. For example, Wu et al.'s (2020a) analysis of carsharing in London indicates that infrequent customers often use carsharing to transport bulky luggage while frequent customers are typically commuters. According to Jian et al. (2017), while high-income customers who choose more luxurious brands use carsharing for leisure and business purposes, lower-income customers often use carsharing for special purposes like vans for moving or traveling with large groups of people.

Many individuals who register for carsharing schemes are not necessarily active customers and use the service only occasionally. In the case of Autolib, an early French EV carsharing initiative, frequency of use per customer continued to decline despite increasing membership; as many registered subscribers used the service infrequently, growth did not translate into increased revenues for the provider (Lagadic et al., 2019). This issue is less significant for P2P car owners, who incur very low marginal costs in comparison to B2C providers, who own or lease large fleets (Meelen et al., 2019).

For frequent users, carsharing is not their main mode of transport but is used in combination with other modes (Ruhrort et al., 2014). Carsharing customers are more likely than car owners to use other complementary mobility services such as bike sharing, walking and public transport (Clewlow, 2016: Mishra et al., 2015; Münzel et al., 2019). For example, in comparisons of free-floating carsharing and public transport in Spain and Denmark, respectively, Ampudia-Renuncio et al. (2020) and Carrone et al. (2020) reported that freefloating carsharing is often used as a substitute for public transport. Becker et al.'s (2017a)
Carsharing: a systematic literature review 
JOSM 32,6

70

comparative study of station-based and free-floating carsharing schemes in Switzerland reports similar findings.

Multiple studies have discussed the impact of carsharing on car ownership, and whether the need for a personal car is reduced by replacing it with a shared one (e.g. Firnkorn and Müller, 2015; Jochem et al., 2020; Le Vine and Polak, 2019). While findings vary, some studies report evidence of a reduction in car ownership as a result of carsharing. For example, in a survey of B2C carsharing members in Seoul, South Korea, Ko et al. (2019) estimated that each shared car replaced 3.3 private cars. Similarly, a study of B2C carsharing providers in Germany found that car owners who adopted carsharing tended to use their own car less frequently (Loose et al., 2006).

3.4.2 Trust. While trust is an important issue for all business models, its significance differs for B2C and P2P models. Several studies note the particular importance of trust for P2P carsharing; for example, in a study of German P2P providers, Wilhelms et al. (2017a) found that trust between car owners and customers was important, especially in relation to car usage behavior and maintenance. In their comparative study of $\mathrm{B} 2 \mathrm{C}$ and $\mathrm{P} 2 \mathrm{P}$ carsharing, Hartl et al. (2018) also found that because P2P carsharing involves transactions between strangers, the potentially higher economic risks and lack of regulation make trust more important. When offered a choice between B2C and P2P carsharing, customers tended to choose $\mathrm{B} 2 \mathrm{C}$ because interacting with a company was perceived as less risky than with an individual. Similarly, Julsrud and Farstad (2020) reported that customers regarded B2C carsharing as (more) trustworthy and professional. According to Ma et al. (2020), trust can affect customer loyalty both directly and indirectly, prompting service providers to address this challenge by eliminating factors that might lead to loss of customer trust, such as high transaction costs. Table 5 summarizes the main reported usage characteristics of carsharing customers.

3.4.3 Customer misbehavior. As a form of service cocreation, the carsharing system involves customer interdependency in ensuring that the car is in good condition for the next customer (Bardhi and Eckhardt, 2012). Schaefers et al. (2016b) investigated misbehavior

\begin{tabular}{|c|c|c|}
\hline $\begin{array}{l}\text { Usage } \\
\text { characteristic }\end{array}$ & Key studies & Key points \\
\hline Trip purpose & $\begin{array}{l}\text { Clark et al. (2015), Costain et al. (2012), } \\
\text { de Lorimier and El-Geneidy (2013), Loose } \\
\text { et al. (2006), Sioui } \text { et al. (2012) }\end{array}$ & $\begin{array}{l}\text { B2C: individual use for leisure trips } \\
\text { B2B: work-related trips }\end{array}$ \\
\hline Trip activity & $\begin{array}{l}\text { Charoniti et al. (2020), Jian et al. (2017), } \\
\text { Wu et al. (2020a) }\end{array}$ & $\begin{array}{l}\text { A smaller car may suffice when commuting } \\
\text { or traveling to a meeting; heavy-duty } \\
\text { purposes (e.g. moving goods) may require a } \\
\text { larger car }\end{array}$ \\
\hline Frequency of use & Paundra et al. (2017), Münzel et al. (2019) & $\begin{array}{l}\text { Carsharing customers are not necessarily } \\
\text { frequent users; many use the service only } \\
\text { occasionally }\end{array}$ \\
\hline $\begin{array}{l}\text { Multimodal } \\
\text { mobility }\end{array}$ & $\begin{array}{l}\text { Ampudia-Renuncio et al. (2020), Becker } \\
\text { et al. (2017a), Carrone } \text { et al. (2020), Clewlow } \\
\text { (2016), Mishra et al. (2015), Münzel } \text { et al. } \\
\text { (2019) }\end{array}$ & $\begin{array}{l}\text { Frequent travelers tend to combine use of } \\
\text { carsharing with other modes of mobility } \\
\text { such as walking and biking }\end{array}$ \\
\hline $\begin{array}{l}\text { Influence on car } \\
\text { ownership }\end{array}$ & $\begin{array}{l}\text { Firnkorn and Müller (2015), Jochem et al. } \\
\text { (2020), Ko et al. (2019), Le Vine and Polak } \\
\text { (2019), Loose et al. (2006) }\end{array}$ & $\begin{array}{l}\text { Some studies report evidence of a reduction } \\
\text { in car ownership as a result of engagement } \\
\text { in carsharing }\end{array}$ \\
\hline Trust & $\begin{array}{l}\text { Hartl et al. (2018), Julsrud and Farstad } \\
\text { (2020), Ma et al. (2020), Wilhelms et al. } \\
\text { (2017a) }\end{array}$ & $\begin{array}{l}\text { Trust is especially relevant for } \mathrm{P} 2 \mathrm{P} \\
\text { carsharing because of the higher economic } \\
\text { risks and the absence of regulation }\end{array}$ \\
\hline
\end{tabular}

Table 5.

Main usage characteristics of carsharing customers et al. (2017a), Carrone et al. (2020), Clewlow (2016), Mishra et al. (2015), Münzel et al. Firnkorn and Müller (2015), Jochem et al. (2020), Ko et al. (2019), Le Vine and Polak (2019), Loose et al. (2006) Hartl et al. (2018), Julsrud and Farstad (2017a)
B2C: individual use for leisure trips B2B: work-related trips

A smaller car may suffice when commuting or traveling to a meeting; heavy-duty purposes (e.g. moving goods) may require a . frequent users; many use the seces occasionally

Frequent travelers tend to combine use of carsharing with other modes of mobility such as walking and biking

Some studies report evidence of a reduction carsharing because of the higher economic risks and the absence of regulation 
among users of sharing services such as carsharing and identified a parallel with broken windows theory, in that one customer's misbehavior affects the next customer's behavior - in other words, misbehavior can be contagious. However, as the opposite is true in groups exhibiting high communal identification, it was considered more useful for service providers to strengthen their brand identity rather than investing in surveillance. Bardhi and Eckhardt (2012) conducted 40 interviews with Zipcar customers and found no sense of perceived ownership when using a car; in some cases, users preferred not to be associated with carsharing services. According to Schaefers et al. (2016b), the contagious effects of customer misbehavior suggest that deanonymizing service providers and customers may help to reduce misbehavior. In an experiment on motivating car inspection, Namazu et al. (2018) found that in the absence of a reminder, most customers did not inspect the car before use. Other undesirable behaviors such as late car return are more likely among P2P users than in B2C carsharing because customers may believe it is easier to discuss misbehavior with an individual than with a company (Namazu et al., 2018).

\subsection{Vehicle balancing}

This aspect of one-way carsharing remains challenging for many providers of access-based services. In one-way carsharing, a short-term imbalance of cars often occurs at certain locations because of the uneven distribution of cars, that is, cars may be unavailable where they are needed while oversupplied at redundant locations. This is a likely consequence of flexible return times and locations, and the uneven flow of cars between stations means there may be too few cars at popular pick-up points (Nair and Miller-Hooks, 2011). The issue of vehicle imbalance is especially challenging for $\mathrm{B} 2 \mathrm{C}$ providers as this business model most commonly offers one-way carsharing. The lack of adequate data makes it more difficult to resolve this problem (Ren et al., 2020), and some studies have developed demand forecasting models to predict carsharing demand in pursuit of optimal business performance and customer satisfaction (e.g. Moein and Awasthi, 2020; Müller et al., 2017). The next section discusses the challenge of selecting appropriate locations for carsharing stations and refers to studies that address the issue of vehicle relocation.

3.5.1 Station location. Appropriate station selection includes identification of lucrative locations (Cheng et al., 2019) and ease of relocating cars between stations to meet demand (Boyaci et al., 2015). In many cases, limited access means that some potential customers may be excluded, while those who can access the cars may not use them. Clark and Curl (2016), who studied UK bicycle and carsharing schemes, noted the importance of the station location in efforts to target potential and willing customers.

Hua et al. (2019) proposed an innovative framework for the deployment of one-way EV carsharing. They emphasized that identification of suitable stations is even more important for EV carsharing fleets because of issues such as battery charging and fluctuating travel time and demand. Seeking to identify optimal charging locations for one-way EV carsharing, Deza et al. (2020) showed how this can maximize balanced flow in carsharing networks. Given the uncertainty of travel demand, simulation models have been used to aid identification of optimal charging station locations for EV fleets (e.g. Brandstätter et al., 2020; Kuwahara et al., 2020; Lu et al., 2020) and to assist fleet allocation (e.g. Deveci et al., 2018). In their investigation of the factors that affect turnover at carsharing stations, Hu et al. (2018) found that in addition to spatial and temporal elements, station-level turnover and the relationship between transit and carsharing affect the use of shared cars. In identifying appropriate locations for carsharing stations, carsharing providers are encouraged to optimize efficiency, especially in densely populated areas, where cars occupy a significant amount of expensive parking space (Hu et al., 2018). Sai et al. (2020) designed a model for EV carsharing and concluded that city population, proportion of available travel modes, station construction costs and budget should be considered when selecting station locations.
Carsharing: a systematic literature review 
JOSM 32,6

3.5.2 Vehicle relocation. Spatio-temporal imbalances in demand for one-way carsharing mean that cars must be constantly redistributed (Balac et al., 2019), relocating them periodically between stations to ensure availability where they are most needed (Kim and Lee, 2017). Any imbalance in distribution makes carsharing less reliable (Balac et al., 2019) and creates complexity barriers (cf. Hazeé et al., 2017) for service providers, who must relocate cars to wherever they are required. Vehicle balancing efforts lead to various trade-offs; for example, Nourinejad and Roorda (2014) evaluated one-way carsharing performance by measuring effectiveness and proposed an optimization model for operational problems involving vehicle relocation. In the proposed model, increased fleet size means reduced time for relocation but also leads to increased costs. As another alternative, the same study proposed that fleet size could be reduced by extending reservation time to about $30 \mathrm{~min}$. However, this might also result in reduced demand, as user privacy could be compromised in some instances by having to specify a return time window to facilitate vehicle relocation forecasting (Repoux et al., 2019).

Over time, vehicle relocation models have been developed for operator-based, user-based and combined vehicle relocation. While operator-based models require staff members to move cars, user-based models rely on customers to do so (Brendel et al., 2018). Testing the impact of vehicle relocation on competition among carsharing operators in Switzerland, Balac et al. (2019) found that to substantially affect demand, more employees are needed to perform the required relocations. Additionally, as cars are unavailable to customers while being relocated, no revenue is earned, making relocation less profitable (Balac et al., 2019). These issues were further highlighted by Kypriadis et al. (2020), who noted that operator-based relocation requires multiple employees to ensure timely relocation. To minimize redundancy, it is also important to coordinate user-based and operator-based relocation (Brendel et al., 2020a). This view is echoed by Huang et al. (2020), who note that user-based and operator-based relocation can be combined on the basis of pricing and the number of shifts, respectively, to correct any vehicle imbalance in one-way carsharing systems. In creating a decision support system for vehicle relocation, Kek et al. (2009) found that customers could be offered incentives in the form of reduced travel costs to encourage compliance with user-based relocation. Alternatively, this can be achieved by allowing customers to choose their own incentive, such as vehicle delivery, alternate pick-up location, alternate drop-off location or paid user relocation (Wu et al., 2020b). Table 6 summarizes key findings related to vehicle relocation models.

Many existing vehicle balancing models are incremental improvements of earlier models. For example, Correia et al. (2014) discussed further options for customer pick-up and car dropoff, and Jorge et al. (2014) combined a mathematical model and a simulation model for optimal vehicle relocation and real-time relocation policy. Unlike simulation models that focus on oneway carsharing, Nourinejad and Roorda (2015) described a bi-modal scheme combining round-trip and one-way modes as one solution to the vehicle relocation problem in one-way carsharing services. Although convenient for customers, one-way services are costly for service providers because they require constant vehicle relocation. In contrast, round-trip systems are convenient for service providers because there is no vehicle relocation requirement, but this is less convenient for customers, who must return the car to its original pick-up point at the end of each trip (Jorge et al., 2015). With the increasing popularity of EV carsharing fleets, more recent models take account of new requirements such as unplugging and recharging (e.g. Boyaci et al., 2015; Weikl and Bogenberger, 2015). For example, based on two optimization models, Caggiani et al. (2020) proposed a shared (vehicle-to-grid) charging system that can help to minimize losses during charging times, so maximizing profits.

\section{Discussion and research agenda}

Despite the growing number of studies on carsharing, service scholars have shown surprisingly little interest to date, and there are ample opportunities for further research. 


\begin{tabular}{ll}
\hline Relocation model & Key studies \\
\hline User-based & $\begin{array}{l}\text { Brendel } \text { et al. }(2018), \text { Brendel } \text { et al. } \\
(2020 \mathrm{~b}), \text { Kek } \text { et al. }(2009)\end{array}$
\end{tabular}
(2020b), Kek et al. (2009)

Operator-based

Combination of userbased and operatorbased

Brendel et al. (2020a), Huang et al. (2020), Wang et al. (2020)
Key points

(1) Cost efficient, as there are no customer-less trips

(2) Price incentives can be used to encourage customers to engage in vehicle relocation

(3) Less reliable, as customer compliance is not guaranteed

Bruglieri et al. (2014), Kek et al. (2009), Nourinejad et al. (2015), Repoux et al. (2019), Santos and de Almeida Correia (2019), Weikl and Bogenberger (2013)
(1) Relocation and maintenance can be combined

(2) Reliable, as relocation is performed by staff

(3) Costly, as customer-less trips are made

(4) Requires service providers to account for staff relocation

(1) Coordination of user-based and operator-based models limits redundancy

(2) Potential to reduce unnecessary waste of resources while improving vehicle circulation and utilization
Carsharing: a systematic literature review

73

Table 6. User-based and operator-based relocation models

As our review indicates, transport and engineering studies predominate, advancing solutions to challenges like vehicle balancing. Based on our systematic review of the literature, we identified four themes as the basis for a service research agenda encompassing theory development and managerial practice. The proposed agenda addresses critical factors for the further growth of carsharing, including customer requirements, balancing supply and demand, and the effects of carsharing on car shedding. While ongoing experimentation continues to explore why certain provisions work better in some locations and markets than in others, a wide range of tools and methods is already available to address pressing issues such as the societal relevance of carsharing ventures and how best to ensure their success.

The research agenda addresses four key areas and associated questions, including key issues for managers and policymakers (see Table 7). While several of these topics are specific to carsharing services, we believe they also have broader ramifications for other mobility service issues, including multi-modal mobility and the rental/access paradigm in general (Lovelock and Gummesson, 2004). As our review illustrates, there is considerable heterogeneity in terms of business models and service systems across the various forms of mobility service. Even in the case of similar value propositions such as $\mathrm{B} 2 \mathrm{C}$ and $\mathrm{P} 2 \mathrm{P}$ carsharing, there are fundamental differences between their respective access-based and platform-based models and systems. Our findings also provide relevant insights and research directions for other forms of nonownership, shared use of other goods, or other types of shortterm access to goods (e.g. bike sharing).

Carsharing is part of the wider shift from products to services commonly referred to as servitization. Although servitization research is among the most active domains in the field of service research and attracts interest from multiple disciplines, it has focused almost exclusively on B2B markets (Raddats et al., 2019). In light of the rapid growth of servitization initiatives in consumer markets (e.g. subscription-as-a-service, sharing economy offerings), there is a need for a systematic overview and a roadmap for future research directions. In this context, it also seems timely to look at carsharing from a wider service management perspective as a market driven by technological and digital transformation. 

JOSM
32,6
Key research questions

Key managerial issues

Research area 1: critical factors for the growth of carsharing

(1) What conditions are necessary for the growth of (1) To identify possible solutions for B2C carsharing B2C carsharing? growth and to understand how these can be implemented

(2) What critical mass is required for the success of different types of carsharing service?

(2) To gain further insights into maximum car utilization

(3) How can insights from specific business models be harnessed to promote growth of other models and synergies between multiple models?

(4) How can service providers harness new technologies and usage data to drive innovation?

(3) To identify solutions that are accessible to a diverse range of customers

(4) To secure the competences needed to manage digital transformation and the "softwareization" of the industry

Research area 2: customer characteristics and requirements

(1) How can customer and service provider goals be (1) To acquire knowledge relevant to the alignment of better aligned to devise balanced solutions for carsharing growth?

(2) What payment schemes are carsharing customers willing to accept?

(3) What lessons can be learned from developing economies to promote the growth of carsharing?

service provider and customer requirements

(2) To promote interest in and acceptance of carsharing across diverse customer segments and markets (3) To identify alternative and unconventional solutions to existing carsharing challenges

Research area 3: addressing the imbalance between demand and supply

(1) How can a balance be struck between fleet size and costs?

(2) How can research on user-based relocation models help to solve the problem of vehicle balancing in one-way carsharing?

(3) What are the unresolved challenges for existing vehicle relocation models?

(1) To better understand the trade-offs in balancing costs and profits

(2) To advance knowledge of user-based models and to validate their ability to solve vehicle balancing problems

(3) To enhance understanding and advance research on vehicle balancing strategies

Research area 4: understanding the effects of carsharing on car shedding

(1) Under what conditions will carsharing encourage (1) To position carsharing schemes more effectively in car shedding?

Table 7.

Research agenda and managerial implications
(2) What are the impacts of various carsharing modes on car ownership?

(3) How can advances in digital technology help to facilitate more seamless mobility experiences? contrast to car ownership

(2) To develop an understanding of service outcomes that can guide resource allocation

(3) To acquire and leverage customer data to align customer preferences and policy goals

\subsection{Critical factors for the growth of carsharing}

Despite the evidence that some carsharing service providers are struggling, as seen in the closures across different markets, little of the existing research has sought to develop a better understanding of the key challenges. The present study identifies four main directions for future research. First, it will be important to identify the conditions necessary for the growth of carsharing. Carsharing is known to scale with population density and social activity - for example, in metropolitan cities (Clewlow, 2016) - and is also more prevalent in areas with lower car ownership and efficient public transport (Becker et al, 2017b). However, a comparison of carsharing services and levels of substitution for other transport modes shows that carsharing usage levels remain low (Rotaris et al., 2019). To address this issue, researchers should explore the factors impeding the progress of carsharing and how these can be managed.

Second, while studies point to high population density as a requirement for successful operation of carsharing, the required critical mass of users remains an unresearched issue. Studies of access-based carsharing have shown that most businesses need to achieve a 
critical mass to break even (Acheampong and Siiba, 2020; Lagadic et al., 2019; Terama et al., 2018). However, this is effectively a chicken-and-egg problem; while a critical mass of service users is required for scalability, users must be able to see scalability before being convinced to abandon their private cars in favor of carsharing. Furthermore, many members of carsharing schemes are not necessarily active customers, as many of those who register for these services use them only occasionally. As mentioned earlier, cost issues make this a more significant problem for $\mathrm{B} 2 \mathrm{C}$ providers than for $\mathrm{P} 2 \mathrm{P}$ owners and platform providers. Further research on the critical mass of users needed for different business models may enable service providers to solve the problem of maximum vehicle utilization.

Third, carsharing research should explore the different business models in greater depth to understand how they can be harnessed to promote carsharing, either as standalone models or in combination. As most research to date has focused on $\mathrm{B} 2 \mathrm{C}$ carsharing, further research should place greater emphasis on $\mathrm{P} 2 \mathrm{P}$ and $\mathrm{B} 2 \mathrm{~B}$ models. For example, as trust is an especially important issue for $\mathrm{P} 2 \mathrm{P}$ carsharing, it would be useful to analyze how peer service providers can enhance profits by gaining their customers' trust (Benoit et al., 2017). This in turn should contribute to the identification of underlying success factors that can be generalized to various forms of access-based carsharing. In practice, many commercial providers offer parallel B2C and B2B services and may have to do so to achieve the requisite utilization rate. Researchers should seek to determine how synergies between business models can best be managed and developed.

Finally, as technology plays an important role in the growth of carsharing, future research should explore how recent and imminent technological advances in the automotive sector can be harnessed to drive innovation and enhance the customer experience of carsharing. For example, some providers have incorporated EVs into carsharing fleets as a means of promoting sustainability and optimizing operational costs (Jacquillat and Zoepf, 2018). However, the challenges associated with EV fleets, including customers' inexperience and the need for a distinct service system, remain to be addressed. Advances in driving automation technology also afford opportunities to utilize customer data to provide better services for customers. Further research on these issues can help carsharing service providers to develop the competences they need to manage the industry's digital transformation.

\subsection{Key customer requirements}

Carsharing adoption has been attributed to the potential for exploiting the benefits of car ownership without bearing the costs (Shaheen et al., 1998). At present, the known prerequisites include collaboration and transparency between stakeholders, demand synchronization, solutions for a diverse group of customers that are accessible and easy to use and adopt, the potential to combine mobility of people and goods, and public information about the availability of mobility services (Eckhardt et al.,2019). However, service researchers have made only limited efforts to identify the key customer requirements for an optimal carsharing experience. On that basis, we can identify three key areas for future research.

First, while extensive research has focused on the customer, including customer behavior, drivers and barriers (especially in relation to access-based business models), few studies have addressed the motives of carsharing service providers. Different types of providers (e.g. pure service firms or automotive manufacturers) may have different reasons for venturing into carsharing, reflecting two broad and fundamentally distinct business models: car sales and leasing (which is managed primarily through third-party dealers) and carsharing. Future studies on service providers can also contribute to the development of balanced solutions based on better alignment of the service provider and customer requirements. Additionally, the perspective of car owners who rent their cars for $\mathrm{P} 2 \mathrm{P}$ carsharing has been neglected by existing research (Hazée et al., 2020).
Carsharing: a systematic literature review 
JOSM 32,6

A second direction for further research relates to payment schemes. To promote maximum car utilization and customer satisfaction, some studies (e.g. Le Vine et al., 2014; Molnar and de Almeida Correia, 2019) have proposed the introduction of reservation systems to eliminate the current first-come-first-served approach. However, while such systems might seem to address the challenge of maximum utilization, they may have an opposite effect on long-term customer satisfaction, as customers are more willing to pay for a guaranteed reservation than for virtual queuing (Wu et al., 2020a). The different types of carsharing providers have experimented with various pricing and payment schemes, such as pay-peruse or P2P's dynamic pricing based on time and usage. Lovelock and Gummesson (2004) proposed that pricing access-based services should relate to units of time but also noted that pricing schemes may need to be modified according to circumstance. Dowling et al.'s (2020) analysis of how users choose between different payment plans showed that carsharing customers typically opt for pay-per-use favor flexibility but tend to underestimate their usage. In general, further research is warranted on perceived utility and willingness to pay, as this may yield solutions to issues of scalability and stakeholder goal alignment.

A final area of concern is that much of the existing research has focused on developed countries in Europe, North America and Asia (including China) while neglecting developing economies with lower purchasing power parity. These less developed countries (in Africa, Asia and Latin America) account for the greater part of the world's population and stand for essentially all world population growth. Many of these markets are undergoing rapid urbanization but often lack efficient public transport and suffer from traffic congestion and poor air quality. As Lovelock and Gummesson (2004) noted, people in developing countries often find ways of improving their prospects through innovative sharing of goods and services. While such practices may not be directly replicable, mobility solutions in these markets may provide valuable insights for improving overall quality of life. Future research should seek to identify the key requirements for progressing carsharing in different customer groups and how these can be implemented in markets with service systems or institutional arrangements that differ fundamentally from high-income economies.

\subsection{Addressing the balance between supply and demand}

This problem occurs mainly in schemes that operate one-way carsharing although it is also relevant to the challenges of vehicle balancing management in general. To date, research in this area has been largely confined to the fields of computer science, engineering and mathematics, focusing mainly on simulation models to assist vehicle balancing. We contend that service researchers can address the imbalance between vehicle supply and demand in three areas.

First, it is clear from the various trade-offs associated with different approaches to vehicle balancing that there is no quick fix for this problem in the context of one-way carsharing. Specifically, service providers must choose between increased costs, reducing the time spent relocating vehicles and reduced customer demand. Service researchers should examine ways of striking a better balance between fleet size/mix and fixed and variable costs by incorporating factors such as customer preferences and behavior.

Second, while a number of studies have advanced user-based vehicle relocation models or a combination of user-based and operator-based models as cost-saving alternatives for vehicle balancing, there is some skepticism about customers' willingness to participate in vehicle relocation, regardless of incentives offered (Brendel et al., 2020b). The question of whether user-based relocation models offer a viable solution remains unanswered in the absence of empirical studies to test these claims. Further research should therefore include empirical studies of user-based vehicle relocation as an alternative or a complement to 
operator-based relocation, as well as the range of customer motivations and their effects on engagement, usage and loyalty.

Finally, despite growing research interest and ongoing development of new relocation models, some issues remain unresolved. For example, as some relocation models are contextspecific and refer to parameters for the city in question, generalizability is limited (e.g. Boyaci et al., 2015; Di Febbraro et al., 2018). Nevertheless, any lessons learned from these contextspecific models should be disseminated to enhance general understanding and to inform further research on vehicle balancing strategies. Additionally, the interdependence of supply and demand is a crucial issue for the design of carsharing schemes but is often neglected in vehicle relocation models (Jian et al., 2019). Finally, questions remain to be answered regarding the optimal inventory level at each carsharing station (Laporte et al., 2018).

\subsection{The effect of carsharing on car shedding}

One matter of longstanding debate is whether carsharing might reduce traffic congestion by encouraging car shedding. Dowling and Simpson (2013) predicted that people's relationship with their cars would change, and that young people in particular would increasingly favor carsharing. This resonates with industry forecasts of a cultural shift in which the car ceases to be an object of ownership and instead becomes part of a service or a network of vehicles for collective use. However, in a study examining the effects of free-floating carsharing on the purchase of new vehicles in cities, Schmidt (2020) found that the claim that one shared car eliminates roughly three car purchases annually does not apply to high status cars such as SUVs or larger vehicles like vans. Similarly, Li and Kamargianni's (2020) research on how carsharing affects private car ownership and public transport demand established that people who take long trips are less likely to give up their private car in favor of carsharing. As one may reasonably assume that $\mathrm{P} 2 \mathrm{P}$ sharing is also a less attractive option in such cases, the debate around carsharing as a means of reducing car traffic remains unresolved.

Further research on this topic should address three issues. First, the conditions under which carsharing might encourage car shedding remain unclear, and further research is needed. Ikezoe et al.'s (2020) survey of car owners in Japan found that car owners tend to have an emotional attachment to their cars and would only abandon them if carsharing tapped into factors beyond economic rationality (such as convenience). To position access-based and platform-based carsharing services as an attractive alternative to car ownership, researchers should explore the nature and impact of these underlying factors.

A second research direction relates to the fact that customer willingness to forego car purchases after joining a carsharing scheme may be contingent on carsharing type (Mishra et al., 2015). For example, round-trip customers are more likely to abandon private ownership if they reduce that dependency by adopting other modes of mobility such as walking or biking. In contrast, one-way customers employ carsharing to replace modes such as taxi and ride hailing (Lempert et al., 2019). Further research should therefore strive for a deeper understanding of how the various carsharing models impact car shedding. Such insights would help to develop an understanding of service outcomes that can guide resource allocation in carsharing schemes.

Finally, more research is needed to specify the ideal conditions for the co-existence of carsharing and other transport modes such as public transport and biking, both as separate services and for multimodal mobility. Contrary to popular belief, carsharing alone may not suffice to encourage car shedding but is more likely to succeed if combined with other transport modes. In fact, access-based carsharing is often most successful when combined with other complementary transport options (Csonka and Csiszár, 2016; Shaheen et al., 1998). Future research should also explore how digital technology can be used to facilitate seamless multi-modal mobility services that align customer preferences and policy goals.

Carsharing: a systematic literature review 
JOSM 32,6

\section{Conclusions and implications for practice}

As evidenced by a growing number of publications over the last five years, carsharing has attracted significant attention from scholars, industry stakeholders and government organizations, reflecting ongoing challenges and the need for innovative mobility solutions. The aims of this literature review were to synthesize the extensive existing literature and to identify key areas for future research. Using a systematic approach, the review analyzed 279 studies published between 1996 and 2020, addressing issues that include existing business models, customer behavior, and user drivers and barriers, as well as the ongoing challenge of vehicle balancing. On that basis, we advanced a research agenda to address critical issues and to propose how existing challenges and opportunities can best be managed.

\subsection{Managerial implications}

The review identifies three main implications for carsharing service providers. First, managers need to understand the importance of building relationships with a wider range of stakeholders, especially when dealing with EV fleets. They must also understand the importance of customer and market factors; for example, while providers may be involved in the design of greenfield service systems from an early stage, initiatives in densely populated areas are different because parking space and charging infrastructure are scarce resources. Similarly, the requirements for P2P carsharing may differ significantly from B2C and B2B contexts. In every case, managers must understand customer needs, shape expectations and articulate potential benefits in terms of the appropriate service business model and ecosystem.

Second, managers must pursue innovations that will help to make carsharing attractive to the wider population; for example, Jian et al. (2020) suggested providing shared parking spaces for carsharing customers rather than simply providing carsharing services as is the current norm. This would enable carsharing service providers to make a profit by renting parking spaces from parking suppliers and then renting the same spaces to carsharing customers at a higher price. This would in turn deliver a higher utilization rate and a further increase in profits. Managers should also look to exploit ongoing technological advances to achieve synergies between business models, for instance, by leveraging customer data to reveal user patterns and so facilitate maximum utilization.

Finally, by targeting a broad base of customers through collaboration with other mobility providers (such as public transport), managers can identify key competences that can be utilized or synchronized to improve services. To that end, it will also be important to assess the potential market size in order to anticipate the impact of other mobility modes and to identify usage patterns that will optimize utilization rates and customer engagement.

\subsection{Policy implications}

For those making and implementing public policy, the present review has two main implications. First, given the potential of carsharing to resolve many pressing societal and environmental challenges such as traffic congestion and air pollution, such initiatives warrant the support of public and private stakeholders alike. However, policy interventions cannot simply support carsharing at the expense of public transport, nor can they enforce policies that simply make carsharing attractive to non-car owners; instead any such intervention must balance and direct provisions to maximize societal benefit. While service providers are often motivated by profit, regulatory bodies are driven by their duty to protect the interests of both users and providers (Lindloff et al., 2014) and must therefore base supports on assessments of local need and the common good. Rather than undermining support for public transport and funding, policy can make carsharing a more attractive alternative to car ownership through a combination of rewards and penalties, for example, lower taxes on revenues from $\mathrm{P} 2 \mathrm{P}$ carsharing in combination with more restricted or more 
expensive public parking. Policies should not simply aim to make carsharing more attractive, as this may prove counterproductive by attracting non-car owners who would otherwise use public transport.

Secondly, to improve traffic conditions and pollution, more support should be provided for EV carsharing fleets, engaging actively with challenges such as the provision of optimized charging stations. In their study of the optimal use of EVs in carsharing, Abouee-Mehrizi et al. (2021) identified three key factors: charging speed, charging station availability and battery range (in that order). Even if most carsharing users are not driving long distances, providers need to ensure that their fleets are charged - ideally, where they are parked. Automotive manufacturer Tesla owns and operates the largest global-charging network in the world $(25,000+$ Superchargers as of June 2021), but too much reliance on commercial actors may create brand-specific lock-in effects that inhibit growth and provision of the necessary infrastructure for local ventures. In short, public decision makers can play a more active role in facilitating the shift to electrification and shared mobility.

\section{References}

Abouee-Mehrizi, H., Baron, O., Berman, O. and Chen, D. (2021), "Adoption of electric vehicles in car sharing market”, Production and Operations Management, Vol. 30 No. 1, pp. 190-209.

Acheampong, R.A. and Siiba, A. (2020), "Modelling the determinants of car-sharing adoption intentions among young adults: the role of attitude, perceived benefits, travel expectations and socio-demographic factors", Transportation, Vol. 47 No. 5, pp. 2557-2580.

Alencar, V.A., Rooke, F., Cocca, M., Vassio, L., Almeida, J. and Vieira, A.B. (2019), "Characterizing client usage patterns and service demand for car-sharing systems", Information Systems, Article in press, 101448.

Alfian, G., Rhee, J., Kang, Y.S. and Yoon, B. (2015), "Performance comparison of reservation based and instant access one-way car sharing service through discrete event simulation", Sustainability, Vol. 7 No. 9, pp. 12465-12489.

Ampudia-Renuncio, M., Guirao, B., Molina-Sánchez, R. and de Alvarez, C.E. (2020), "Understanding the spatial distribution of free-floating carsharing in cities: analysis of the new Madrid experience through a web-based platform”, Cities, Vol. 98, p. 102593.

Balac, M., Ciari, F. and Axhausen, K.W. (2017), "Modeling the impact of parking price policy on freefloating carsharing: case study for Zurich, Switzerland", Transportation Research Part C: Emerging Technologies, Vol. 77, pp. 207-225.

Balac, M., Becker, H., Ciari, F. and Axhausen, K.W. (2019), "Modeling competing free-floating carsharing operators-A case study for Zurich, Switzerland", Transportation Research Part C: Emerging Technologies, Vol. 98, pp. 101-117.

Ballús-Armet, I., Shaheen, S.A., Clonts, K. and Weinzimmer, D. (2014), "Peer-to-peer carsharing: exploring public perception and market characteristics in the San Francisco Bay area, California", Transportation Research Record, Vol. 2416 No. 1, pp. 27-36.

Barbour, N., Zhang, Y. and Mannering, F. (2020), "Individuals' willingness to rent their personal vehicle to others: an exploratory assessment of peer-to-peer carsharing", Transportation Research Interdisciplinary Perspectives, Vol. 5, p. 100138.

Bardhi, F. and Eckhardt, G.M. (2012), "Access-based consumption: the case of car sharing”, Journal of Consumer Research, Vol. 39 No. 4, pp. 881-898.

Barnes, S.J. and Mattsson, J. (2016), "Understanding current and future issues in collaborative consumption: a four-stage Delphi study", Technological Forecasting and Social Change, Vol. 104, pp. 200-211.

Becker, H., Ciari, F. and Axhausen, K.W. (2017a), "Comparing car-sharing schemes in Switzerland: user groups and usage patterns", Transportation Research Part A: Policy and Practice, Vol. 97, pp. 17-29.
Carsharing: a systematic literature review 
JOSM 32,6

Becker, H., Ciari, F. and Axhausen, K.W. (2017b), "Modeling free-floating car-sharing use in Switzerland: a spatial regression and conditional logit approach", Transportation Research Part C: Emerging Technologies, Vol. 81, pp. 286-299.

Becker, H., Ciari, F. and Axhausen, K.W. (2018), "Measuring the car ownership impact of free-floating car-sharing-A case study in Basel, Switzerland", Transportation Research Part D: Transport and Environment, Vol. 65, pp. 51-62.

Bellos, I., Ferguson, M. and Toktay, L.B. (2017), "The car sharing economy: interaction of business model choice and product line design", Manufacturing and Service Operations Management, Vol. 19 No. 2, pp. 185-201.

Benoit, S., Baker, T.L., Bolton, R.N., Gruber, T. and Kandampully, J. (2017), "A triadic framework for collaborative consumption (CC): motives, activities and resources and capabilities of actors", Journal of Business Research, Vol. 79, pp. 219-227.

Bocken, N., Jonca, A., Södergren, K. and Palm, J. (2020), "Emergence of carsharing business models and sustainability impacts in Swedish cities", Sustainability, Vol. 12 No. 4, p. 1594.

Boell, S.K. and Cecez-Kecmanovic, D. (2015), "On being 'systematic' in literature reviews", Journal of Information Technology, Vol. 30, pp. 161-173.

Boldrini, C., Bruno, R. and Laarabi, M.H. (2019), "Weak signals in the mobility landscape: car sharing in ten European cities", EPJ Data Science, Vol. 8 No. 1, p. 7.

Bonsall, P., Jopson, A., Pridmore, A., Ryan, A. and Firmin, P. (2002), "Car share and car clubs: potential impacts", Department of Transport (Great Britain), Local Government and the Regions and the Motorists Forum, London.

Boyaci, B., Zografos, K.G. and Geroliminis, N. (2015), “An optimization framework for the development of efficient one-way car-sharing systems", European Journal of Operational Research, Vol. 240 No. 3, pp. 718-733.

Brandstätter, G., Leitner, M. and Ljubić, I. (2020), "Location of charging stations in electric car sharing systems", Transportation Science, Vol. 54 No. 5, pp. 1408-1438.

Brendel, A.B., Lichtenberg, S., Brauer, B., Nastjuk, I. and Kolbe, L.M. (2018), "Improving electric vehicle utilization in carsharing: a framework and simulation of an e-carsharing vehicle utilization management system", Transportation Research Part D: Transport and Environment, Vol. 64, pp. 230-245.

Brendel, A.B., Brennecke, J.T., Hillmann, B.M. and Kolbe, L.M. (2020a), "The design of a decision support system for computation of carsharing pricing areas and its influence on vehicle distribution", IEEE Transactions on Engineering Management, Article in press, pp. 1-15.

Brendel, A.B., Lichtenberg, S., Prinz, C. and Herrenkind, B. (2020b), "Increasing the value of shared vehicles: insights from an implementation of user-based relocation in station-based one-way carsharing”, Sustainability, Vol. 12 No. 21, p. 8800.

Bruglieri, M., Colorni, A. and Luè, A. (2014), "The relocation problem for the one-way electric vehicle sharing", Networks, Vol. 64 No. 4, pp. 292-305.

Burlando, C., Ivaldi, E., Saiani, P.P. and Penco, L. (2019), "To own or not to own? Car ownership and consumer awareness: evidence from an Italian survey", Research in Transportation Business and Management, Vol. 33, p. 100435.

Caggiani, L., Prencipe, L.P. and Ottomanelli, M. (2020), "A static relocation strategy for electric carsharing systems in a vehicle-to-grid framework", Transportation Letters, Article in press, pp. 1-10.

Carrone, A.P., Hoening, V.M., Jensen, A.F., Mabit, S.E. and Rich, J. (2020), "Understanding car sharing preferences and mode substitution patterns: a stated preference experiment", Transport Policy, Vol. 98, pp. 139-147.

Cartenì, A., Cascetta, E. and de Luca, S. (2016), "A random utility model for park and carsharing services and the pure preference for electric vehicles", Transport Policy, Vol. 48, pp. 49-59. 
Charoniti, E., Kim, J., Rasouli, S. and Timmermans, H.J. (2020), "Intrapersonal heterogeneity in car-sharing decision-making processes by activity-travel contexts: a context-dependent latent class random utility-random regret model", International Journal of Sustainable Transportation, Article in press, pp. 1-11.

Cheng, Y., Chen, X., Ding, X. and Zeng, L. (2019), "Optimizing location of car-sharing stations based on potential travel demand and present operation characteristics: the case of chengdu", Journal of Advanced Transportation, Vol. 2019, pp. 1-13.

Chun, Y.-Y., Matsumoto, M., Tahara, K., Chinen, K. and Endo, H. (2019), "Exploring factors affecting car sharing use intention in the Southeast-Asia region: a case study in Java, Indonesia", Sustainability, Vol. 11 No. 18, p. 5103.

Clark, J. and Curl, A. (2016), "Bicycle and car share schemes as inclusive modes of travel? A sociospatial Analysis in Glasgow, UK", Social Inclusion, Vol. 4 No. 3, pp. 83-99.

Clark, M., Gifford, K., Anable, J. and Le Vine, S. (2015), "Business-to-business carsharing: evidence from Britain of factors associated with employer-based carsharing membership and its impacts", Transportation, Vol. 42 No. 3, pp. 471-495.

Clewlow, R.R. (2016), “Carsharing and sustainable travel behavior: results from the san Francisco Bay area”, Transport Policy, Vol. 51, pp. 158-164.

Cohen, B. and Kietzmann, J. (2014), "Ride on! Mobility business models for the sharing economy", Organization and Environment, Vol. 27 No. 3, pp. 279-296.

Cohen, A.P., Shaheen, S. and McKenzie, R. (2008), Carsharing: A Guide for Local Planners, American Planning Association, California.

Coll, M.H., Vandersmissen, M.H. and Thériault, M. (2014), "Modeling spatio-temporal diffusion of carsharing membership in Québec City", Journal of Transport Geography, Vol. 38, pp. 22-37.

Correia, G.H.D.A. and Antunes, A.P. (2012), "Optimization approach to depot location and trip selection in one-way carsharing systems", Transportation Research Part E: Logistics and Transportation Review, Vol. 48 No. 1, pp. 233-247.

Correia, G.H.D.A., Jorge, D.R. and Antunes, D.M. (2014), “The added value of accounting for users' flexibility and information on the potential of a station-based one-way car-sharing system: an application in Lisbon, Portugal”, Journal of Intelligent Transportation Systems, Vol. 18 No. 3, pp. 299-308.

Costain, C., Ardron, C. and Habib, K.N. (2012), "Synopsis of users' behavior of a carsharing program: a case study in Toronto", Transportation Research Part A: Policy and Practice, Vol. 46 No. 3, pp. 421-434.

Cronin, P., Ryan, F. and Coughlan, M. (2008), "Undertaking a literature review: a step-by-step approach", British Journal of Nursing, Vol. 17 No. 1, pp. 38-43.

Csonka, B. and Csiszár, C. (2016), "Service quality analysis and assessment method for European carsharing systems", Periodica Polytechnica Transportation Engineering, Vol. 44 No. 2, pp. 80-88.

de Lorimier, A. and El-Geneidy, A.M. (2013), "Understanding the factors affecting vehicle usage and availability in carsharing networks: a case study of Communauto carsharing system from Montréal, Canada”, International Journal of Sustainable Transportation, Vol. 7 No. 1, pp. 35-51.

De Luca, S. and Di Pace, R. (2015), "Modelling users' behavior in inter-urban carsharing program: a stated preference approach", Transportation Research Part A: Policy and Practice, Vol. 71, pp. 59-76.

del Mar Alonso-Almeida, M. (2019), "Carsharing: another gender issue? Drivers of carsharing usage among women and relationship to perceived value", Travel Behaviour and Society, Vol. 17, pp. 36-45.

Deveci, M., Canıtez, F. and Gökaşar, I. (2018), "WASPAS and TOPSIS based interval type-2 fuzzy MCDM method for a selection of a car sharing station", Sustainable Cities and Society, Vol. 41, pp. 777-791.

Deza, A., Huang, K. and Metel, M.R. (2020), "Charging station optimization for balanced electric car sharing", Discrete Applied Mathematics, Article in press.

Carsharing: a systematic literature review 
JOSM 32,6

Diana, M. and Ceccato, R. (2019), "A multimodal perspective in the study of car sharing switching intentions", Transportation Letters, Article in press, pp. 1-7.

Di Febbraro, A., Sacco, N. and Saeednia, M. (2018), "One-way car-sharing profit maximization by means of user-based vehicle relocation", IEEE Transactions on Intelligent Transportation Systems, Vol. 20 No. 2, pp. 628-641.

Dijk, M., Orsato, R.J. and Kemp, R. (2013), "The emergence of an electric mobility trajectory", Energy Policy, Vol. 52, pp. 135-145.

Dill, J., McNeil, N. and Howland, S. (2019), "Effects of peer-to-peer carsharing on vehicle owners' travel behavior", Transportation Research Part C: Emerging Technologies, Vol. 101, pp. 70-78.

Dowling, R. and Simpson, C. (2013), "Shift-the way you move: reconstituting automobility", Continuum, Vol. 27 No. 3, pp. 421-433.

Dowling, K., Manchanda, P. and Spann, M. (2020), "The existence and persistence of the pay-per-use bias in car sharing services", International Journal of Research in Marketing, Article in press.

Duan, Q., Ye, X., Li, J. and Wang, K. (2020), "Empirical modeling analysis of potential commute demand for carsharing in shanghai, China", Sustainability, Vol. 12 No. 2, p. 620.

Duncan, M. (2011), "The cost saving potential of carsharing in a US context", Transportation, Vol. 38 No. 2, pp. 363-382.

Eckhardt, G.M., Houston, M.B., Jiang, B., Lamberton, C., Rindfleisch, A. and Zervas, G. (2019), "Marketing in the sharing economy", Journal of Marketing, Vol. 83 No. 5, pp. 5-27.

Efthymiou, D., Antoniou, C. and Waddell, P. (2013), "Factors affecting the adoption of vehicle sharing systems by young drivers", Transport Policy, Vol. 29, pp. 64-73.

Fellows, N.T. and Pitfield, D.E. (2000), "An economic and operational evaluation of urban car-sharing", Transportation Research Part D: Transport and Environment, Vol. 5 No. 1, pp. 1-10.

Ferrero, F., Perboli, G., Rosano, M. and Vesco, A. (2018), "Car-sharing services: an annotated review", Sustainable Cities and Society, Vol. 37, pp. 501-518.

Firnkorn, J. and Müller, M. (2012), "Selling mobility instead of cars: new business strategies of automakers and the impact on private vehicle holding", Business Strategy and the Environment, Vol. 21 No. 4, pp. 264-280.

Firnkorn, J. and Müller, M. (2015), "Free-floating electric carsharing-fleets in smart cities: the dawning of a post-private car era in urban environments?", Environmental Science and Policy, Vol. 45, pp. 30-40.

Fleury, S., Tom, A., Jamet, E. and Colas-Maheux, E. (2017), "What drives corporate carsharing acceptance? A French case study", Transportation Research Part F: Traffic Psychology and Behaviour, Vol. 45, pp. 218-227.

Fritze, M.P., Marchand, A., Eisingerich, A.B. and Benkenstein, M. (2020), "Access-based services as substitutes for material possessions: the role of psychological ownership", Journal of Service Research, Vol. 23 No. 3, pp. 368-385.

Giorgione, G., Ciari, F. and Viti, F. (2020), "Dynamic pricing on round-trip carsharing services: travel behavior and equity impact analysis through an agent-based simulation", Sustainability, Vol. 12 No. 17, p. 6727.

Global Market Insights, Inc. (2021), "Car sharing market statistics - global growth trends 2026", available at: https://www.gminsights.com/industry-analysis/carsharing-market (accessed 13 June 2021).

Guglielmetti Mugion, R., Toni, M., Di Pietro, L., Pasca, M. and Renzi, M. (2019), "Understanding the antecedents of car sharing usage: an empirical study in Italy", International Journal of Quality and Service Sciences, Vol. 11 No. 4, pp. 523-541.

Guyader, H. (2018), "No one rides for free! Three styles of collaborative consumption", Journal of Services Marketing, Vol. 32 No. 6, pp. 692-714. 
Hahn, R., Ostertag, F., Lehr, A., Büttgen, M. and Benoit, S. (2020), “I like it, but I don’t use it': impact of carsharing business models on usage intentions in the sharing economy", Business Strategy and the Environment, Vol. 29 No. 3, pp. 1404-1418.

Hamari, J., Sjöklint, M. and Ukkonen, A. (2016), "The sharing economy: why people participate in collaborative consumption", Journal of the Association for Information Science and Technology, Vol. 67 No. 9, pp. 2047-2059.

Hampshire, R.C. and Gaites, C. (2011), "Peer-to-peer carsharing: market analysis and potential growth", Transportation Research Record, Vol. 2217 No. 1, pp. 119-126.

Carsharing: a systematic literature review

Hartl, B., Sabitzer, T., Hofmann, E. and Penz, E. (2018), “Sustainability is a nice bonus' the role of sustainability in carsharing from a consumer perspective", Journal of Cleaner Production, Vol. 202, pp. 88-100.

Hazée, S., Delcourt, C. and Van Vaerenbergh, Y. (2017), "Burdens of access: understanding customer barriers and barrier-attenuating practices in access-based services", Journal of Service Research, Vol. 20 No. 4, pp. 441-456.

Hazée, S., Zwienenberg, T.J., Van Vaerenbergh, Y., Faseur, T., Vandenberghe, A. and Keutgens, O. (2020), "Why customers and peer service providers do not participate in collaborative consumption", Journal of Service Management, Vol. 31, pp. 397-419.

Heilig, M., Mallig, N., Schröder, O., Kagerbauer, M. and Vortisch, P. (2018), "Implementation of freefloating and station-based carsharing in an agent-based travel demand model", Travel Behaviour and Society, Hong Kong Society for Transportation Studies, Vol. 12, pp. 151-158.

Hjorteset, M.A. and Böcker, L. (2020), "Car sharing in Norwegian urban areas: examining interest, intention and the decision to enrol", Transportation Research Part D: Transport and Environment, Vol. 84, p. 102322.

Hofmann, E., Hartl, B. and Penz, E. (2017), "Power versus trust - what matters more in collaborative consumption?", Journal of Services Marketing, Vol. 31 No. 6, pp. 589-603.

Hu, S., Chen, P., Lin, H., Xie, C. and Chen, X. (2018), "Promoting carsharing attractiveness and efficiency: an exploratory analysis", Transportation Research Part D: Transport and Environment, Vol. 65, pp. 229-243.

Hua, Y., Zhao, D., Wang, X. and Li, X. (2019), “Joint infrastructure planning and fleet management for one-way electric car sharing under time-varying uncertain demand", Transportation Research Part B: Methodological, Vol. 128, pp. 185-206.

Huang, K., An, K. and de Almeida Correia, G.H. (2020), "Planning station capacity and fleet size of oneway electric carsharing systems with continuous state of charge functions", European Journal of Operational Research, Vol. 287 No. 3, pp. 1075-1091.

Ikezoe, K., Kiriyama, E. and Fujimura, S. (2020), "Car-sharing intention analysis in Japan by comparing the utility of car ownership for car-owners and non-car owners", Transport Policy, Vol. 96, pp. 1-14.

Jacquillat, A. and Zoepf, S. (2018), "Deployment and utilization of plug-in electric vehicles in round-trip carsharing systems”, International Journal of Sustainable Transportation, Vol. 12 No. 2, pp. 75-91.

Jian, S., Hossein Rashidi, T., Wijayaratna, K.P. and Dixit, V.V. (2016), "A Spatial Hazard-Based analysis for modelling vehicle selection in station-based carsharing systems", Transportation Research Part C: Emerging Technologies, Vol. 72, pp. 130-142.

Jian, S., Rashidi, T.H. and Dixit, V. (2017), "An analysis of carsharing vehicle choice and utilization patterns using multiple discrete-continuous extreme value (MDCEV) models", Transportation Research Part A: Policy and Practice, Vol. 103, pp. 362-376.

Jian, S., Rey, D. and Dixit, V. (2019), "An integrated supply-demand approach to solving optimal relocations in station-based carsharing systems", Networks and Spatial Economics, Networks and Spatial Economics, Vol. 19 No. 2, pp. 611-632.

Jian, S., Liu, W., Wang, X., Yang, H. and Waller, S.T. (2020), "On integrating carsharing and parking sharing services", Transportation Research Part B: Methodological, Vol. 142, pp. 19-44. 
JOSM 32,6

Jochem, P., Frankenhauser, D., Ewald, L., Ensslen, A. and Fromm, H. (2020), "Does free-floating carsharing reduce private vehicle ownership? The case of SHARE NOW in European cities", Transportation Research Part A: Policy and Practice, Vol. 141, pp. 373-395.

Jorge, D. and Correia, G. (2013), "Carsharing systems demand estimation and defined operations: a literature review", European Journal of Transport and Infrastructure Research, Vol. 13 No. 3, pp. 201-220.

Jorge, D., Correia, G.H.A. and Barnhart, C. (2014), "Comparing optimal relocation operations with simulated relocation policies in one-way carsharing systems", IEEE Transactions on Intelligent Transportation Systems, Vol. 15 No. 4, pp. 1667-1675.

Jorge, D., Barnhart, C. and de Almeida Correia, G.H. (2015), "Assessing the viability of enabling a round-trip carsharing system to accept one-way trips: application to Logan Airport in Boston", Transportation Research Part C: Emerging Technologies, Vol. 56, pp. 359-372.

Julsrud, T.E. and Farstad, E. (2020), "Car sharing and transformations in households travel patterns: insights from emerging proto-practices in Norway", Energy Research and Social Science, Vol. 66, p. 101497.

Juschten, M., Ohnmacht, T., Thao, V.T., Gerike, R. and Hössinger, R. (2019), "Carsharing in Switzerland: identifying new markets by predicting membership based on data on supply and demand", Transportation, Vol. 46 No. 4, pp. 1171-1194.

Kang, J., Hwang, K. and Park, S. (2016), "Finding factors that influence carsharing usage: case study in seoul”, Sustainability, Vol. 8 No. 8, p. 709.

Kek, A.G.H., Cheu, R.L., Meng, Q. and Fung, C.H. (2009), “A decision support system for vehicle relocation operations in carsharing systems", Transportation Research Part E: Logistics and Transportation Review, Vol. 45 No. 1, pp. 149-158.

Kent, J., Dowling, R. and Maalsen, S. (2017), "Catalysts for transport transitions: bridging the gap between disruptions and change", Journal of Transport Geography, Vol. 60, pp. 200-207.

Kim, K.H. and Lee, Y.H. (2017), "Vehicle-relocation optimization for one-way carsharing”, International Journal of Industrial Engineering, Vol. 24 No. 5, pp. 468-482.

Kim, J., Rasouli, S. and Timmermans, H.J.P. (2017a), "The effects of activity-travel context and individual attitudes on car-sharing decisions under travel time uncertainty: a hybrid choice modeling approach", Transportation Research Part D: Transport and Environment, Vol. 56, pp. 189-202.

Kim, J., Rasouli, S. and Timmermans, H.J.P. (2017b), "Satisfaction and uncertainty in car-sharing decisions: an integration of hybrid choice and random regret-based models", Transportation Research Part A: Policy and Practice, Vol. 95, pp. 13-33.

Kim, D., Park, Y. and Ko, J. (2019), "Factors underlying vehicle ownership reduction among carsharing users: a repeated cross-sectional analysis", Transportation Research Part D: Transport and Environment, Vol. 76, pp. 123-137.

Ko, J., Ki, H. and Lee, S. (2019), "Factors affecting carsharing program participants' car ownership changes", Transportation Letters, Vol. 11 No. 4, pp. 208-218.

Kuwahara, M., Yoshioka, A. and Uno, N. (2020), "Practical searching optimal one-way carsharing stations to Be equipped with additional chargers for preventing opportunity loss caused by low SoC", International Journal of Intelligent Transportation Systems Research, pp. 1-10.

Kypriadis, D., Pantziou, G., Konstantopoulos, C. and Gavalas, D. (2020), "Optimizing relocation cost in free-floating car-sharing systems", IEEE Transactions on Intelligent Transportation Systems, Vol. 21 No. 9, pp. 4017-4030.

Lagadic, M., Verloes, A. and Louvet, N. (2019), "Can carsharing services be profitable? A critical review of established and developing business models", Transport Policy, Vol. 77, pp. 68-78.

Laporte, G., Meunier, F. and Wolfler Calvo, R. (2018), "Shared mobility systems: an updated survey", Annals of Operations Research, Vol. 271 No. 1, pp. 105-126. 
Le Vine, S. and Polak, J. (2019), "The impact of free-floating carsharing on car ownership: early-stage findings from London”, Transport Policy, Vol. 75, pp. 119-127.

Le Vine, S., Lee-Gosselin, M., Sivakumar, A. and Polak, J. (2014), "A new approach to predict the market and impacts of round-trip and point-to-point carsharing systems: case study of London”, Transportation Research Part D: Transport and Environment, Vol. 32, pp. 218-229.

Lempert, R., Zhao, J. and Dowlatabadi, H. (2019), "Convenience, savings, or lifestyle? Distinct motivations and travel patterns of one-way and two-way carsharing members in Vancouver, Canada”, Transportation Research Part D: Transport and Environment, Vol. 71, pp. 141-152.

Li, W. and Kamargianni, M. (2020), "Steering short-term demand for car-sharing: a mode choice and policy impact analysis by trip distance", Transportation, Vol. 47 No. 5, pp. 2233-2265.

Lindloff, K., Pieper, N., Bandelow, N.C. and Woisetschläger, D.M. (2014), "Drivers of carsharing diffusion in Germany: an actor-centred approach", International Journal of Automotive Technology and Management, Vol. 14 Nos 3-4, pp. 217-245.

Loose, W., Mohr, M. and Nobis, C. (2006), "Assessment of the future development of car sharing in Germany and related opportunities", Transport Reviews, Vol. 26 No. 3, pp. 365-382.

Lovelock, C. and Gummesson, E. (2004), "Whither services marketing? In search of a new paradigm and fresh perspectives", Journal of Service Research, Vol. 7 No. 1, pp. 20-41.

Lu, X., Zhang, Q., Peng, Z., Shao, Z., Song, H. and Wang, W. (2020), "Charging and relocating optimization for electric vehicle car-sharing: an event-based strategy improvement approach", Energy, Vol. 207, p. 118285.

Lyngdoh, T., Chefor, E., Hochstein, B., Britton, B.P. and Amyx, D. (2021), “A systematic literature review of negative psychological states and behaviors in sales", Journal of Business Research, Vol. 122, pp. 518-533.

Ma, F., Guo, D., Yuen, K.F., Sun, Q., Ren, F., Xu, X. and Zhao, C. (2020), "The influence of continuous improvement of public car-sharing platforms on passenger loyalty: a mediation and moderation analysis", International Journal of Environmental Research and Public Health, Vol. 17 No. 8, p. 2756.

Meelen, T., Frenken, K. and Hobrink, S. (2019), "Weak spots for car-sharing in The Netherlands? The geography of socio-technical regimes and the adoption of niche innovations", Energy Research and Social Science, Vol. 52, pp. 132-143.

Miller, J. (2019), "German automakers do U-turn on car-sharing push”, Financial Times.

Mishra, G.S., Clewlow, R.R., Mokhtarian, P.L. and Widaman, K.F. (2015), "The effect of carsharing on vehicle holdings and travel behavior: a propensity score and causal mediation analysis of the San Francisco Bay Area”, Research in Transportation Economics, Vol. 52, pp. 46-55.

Möhlmann, M. (2015), "Collaborative consumption: determinants of satisfaction and the likelihood of using a sharing economy option again”, Journal of Consumer Behaviour, Vol. 14 No. 3, pp. 193-207.

Moein, E. and Awasthi, A. (2020), "Carsharing customer demand forecasting using causal, time series and neural network methods: a case study", International Journal of Services and Operations Management, Vol. 35 No. 1, pp. 36-57.

Moeller, S. and Wittkowski, K. (2010), "The burdens of ownership: reasons for preferring renting", Managing Service Quality: An International Journal, Vol. 20 No. 2, pp. 176-191.

Molnar, G. and de Almeida Correia, G.H. (2019), "Long-term vehicle reservations in one-way freefloating carsharing systems: a variable quality of service model", Transportation Research Part C: Emerging Technologies, Vol. 98, pp. 298-322.

Müller, J., Correia, G.H.D.A. and Bogenberger, K. (2017), "An explanatory model approach for the spatial distribution of free-floating carsharing bookings: a case-study of German cities", Sustainability, Vol. 9 No. 7, p. 1290.

Münzel, K., Boon, W., Frenken, K. and Vaskelainen, T. (2018), "Carsharing business models in Germany: characteristics, success and future prospects”, Information Systems and E-Business Management, Vol. 16 No. 2, pp. 271-291.
Carsharing: a systematic literature review 
JOSM 32,6

Münzel, K., Piscicelli, L., Boon, W. and Frenken, K. (2019), "Different business models-different users? Uncovering the motives and characteristics of business-to-consumer and peer-to-peer carsharing adopters in The Netherlands", Transportation Research Part D: Transport and Environment, Vol. 73, pp. 276-306.

Münzel, K., Boon, W., Frenken, K., Blomme, J. and van der Linden, D. (2020), "Explaining carsharing supply across Western European cities", International Journal of Sustainable Transportation, Vol. 14 No. 4, pp. 243-254.

Nair, R. and Miller-Hooks, E. (2011), "Fleet management for vehicle sharing operations", Transportation Science, Vol. 45 No. 4, pp. 524-540.

Namazu, M., Zhao, J. and Dowlatabadi, H. (2018), "Nudging for responsible carsharing: using behavioral economics to change transportation behavior", Transportation, Vol. 45 No. 1, pp. 105-119.

Nitschke, L. (2020), "Reconstituting automobility: the influence of non-commercial carsharing on the meanings of automobility and the car", Sustainability, Vol. 12 No. 17, p. 7062.

Nourinejad, M. and Roorda, M.J. (2014), "A dynamic carsharing decision support system", Transportation Research Part E: Logistics and Transportation Review, Vol. 66, pp. 36-50.

Nourinejad, M. and Roorda, M.J. (2015), "Carsharing operations policies: a comparison between oneway and two-way systems", Transportation, Vol. 42 No. 3, pp. 497-518.

Nourinejad, M., Zhu, S., Bahrami, S. and Roorda, M.J. (2015), "Vehicle relocation and staff rebalancing in one-way carsharing systems", Transportation Research Part E: Logistics and Transportation Review, Vol. 81, pp. 98-113.

Orski, K. (2001), “Car sharing”, Transport Quaterly, Vol. 55 No. 4, pp. 13-15.

Palmatier, R.W., Houston, M.B. and Hulland, J. (2018), "Review articles: purpose, process, and structure", Journal of the Academy of Marketing Science, Vol. 46 No. 1, pp. 1-5.

Paundra, J., Rook, L., van Dalen, J. and Ketter, W. (2017), "Preferences for car sharing services: effects of instrumental attributes and psychological ownership", Journal of Environmental Psychology, Vol. 53, pp. 121-130.

Perboli, G., Ferrero, F., Musso, S. and Vesco, A. (2018), "Business models and tariff simulation in carsharing services", Transportation Research Part A: Policy and Practice, Vol. 115, pp. $32-48$.

Peterson, M. and Simkins, T. (2019), "Consumers' processing of mindful commercial car sharing", Business Strategy and the Environment, Vol. 28 No. 3, pp. 457-465.

Prieto, M., Baltas, G. and Stan, V. (2017), "Car sharing adoption intention in urban areas: what are the key sociodemographic drivers?", Transportation Research Part A: Policy and Practice, Vol. 101, pp. 218-227.

Raddats, C., Kowalkowski, C., Benedettini, O., Burton, J. and Gebauer, H. (2019), "Servitization: a contemporary thematic review of four major research streams", Industrial Marketing Management, Vol. 83, pp. 207-223.

Ren, C., An, L., Gu, Z., Wang, Y. and Gao, Y. (2020), "Rebalancing the car-sharing system with reinforcement learning”, World Wide Web, Vol. 23 No. 4, pp. 2491-2511.

Repoux, M., Kaspi, M., Boyac1, B. and Geroliminis, N. (2019), "Dynamic prediction-based relocation policies in one-way station-based carsharing systems with complete journey reservations", Transportation Research Part B: Methodological, Vol. 130, pp. 82-104.

Rotaris, L., Danielis, R. and Maltese, I. (2019), "Carsharing use by college students: the case of Milan and Rome", Transportation Research Part A: Policy and Practice, Vol. 120, pp. 239-251.

Ruhrort, L., Steiner, J., Graff, A., Hinkeldein, D. and Hoffmann, C. (2014), "Carsharing with electric vehicles in the context of users' mobility needs - results from user-centred research from the BeMobility field trial (Berlin)", International Journal of Automotive Technology and Management, Vol. 14 Nos 3-4, pp. 286-305.

Rust, R.T. and Cooil, B. (1994), "Reliability measures for qualitative data: theory and implications", Journal of Marketing Research, Vol. 31 No. 1, pp. 1-14. 
Sai, Q., Bi, J. and Chai, J. (2020), "Optimal model for carsharing station location based on multi-factor constraints", Algorithms, Vol. 13 No. 2, p. 43.

Santos, G.G.D. and de Almeida Correia, G.H. (2019), "Finding the relevance of staff-based vehicle relocations in one-way carsharing systems through the use of a simulation-based optimization tool", Journal of Intelligent Transportation Systems: Technology, Planning, and Operations, Vol. 23 No. 6, pp. 583-604.

Schaefers, T. (2013), "Exploring carsharing usage motives: a hierarchical means-end chain analysis", Transportation Research Part A: Policy and Practice, Vol. 47, pp. 69-77.

Schaefers, T., Lawson, S.J. and Kukar-Kinney, M. (2016a), "How the burdens of ownership promote consumer usage of access-based services”, Marketing Letters, Vol. 27 No. 3, pp. 569-577.

Schaefers, T., Wittkowski, K., Benoit (née Moeller), S. and Ferraro, R. (2016b), "Contagious effects of customer misbehavior in access-based services", Journal of Service Research, Vol. 19 No. 1, pp. 3-21.

Schaefers, T., Moser, R. and Narayanamurthy, G. (2018), "Access-based services for the base of the pyramid”, Journal of Service Research, Vol. 21 No. 4, pp. 421-437.

Schmidt, P. (2020), "The effect of car sharing on car sales", International Journal of Industrial Organization, Vol. 71, p. 102622.

Schmöller, S., Weikl, S., Müller, J. and Bogenberger, K. (2015), "Empirical analysis of free-floating carsharing usage: the munich and berlin case", Transportation Research Part C: Emerging Technologies, Vol. 56, pp. 34-51.

Schwabe, J. (2020), "The evolution of cooperative electric carsharing in Germany and the role of intermediaries", Environmental Innovation and Societal Transitions, Vol. 37, pp. 108-119.

Shaheen, S.A. and Cohen, A.P. (2012), "Carsharing and personal vehicle services: worldwide market developments and emerging Trends", International Journal of Sustainable Transportation, Vol. 7 No. 1, pp. 5-34.

Shaheen, S.A. and Martin, E. (2010), "Demand for carsharing systems in Beijing, China: an exploratory study", International Journal of Sustainable Transportation, Vol. 4 No. 1, pp. 41-55.

Shaheen, S., Sperling, D. and Wagner, C. (1998), "Carsharing in Europe and North America: past, present and future", Transport Quaterly, Vol. 52 No. 3, pp. 35-52.

Shaheen, S., Sperling, D. and Wagner, C. (1999), "Carsharing and partnership management: an international perspective”, Transportation Research Record, Vol. 1666 No. 1, pp. 118-124.

Shaheen, S.A., Chan, N.D. and Micheaux, H. (2015), "One-way carsharing's evolution and operator perspectives from the Americas”, Transportation, Vol. 42 No. 3, pp. 519-536.

Sioui, L., Morency, C. and Trépanier, M. (2012), "How carsharing affects the travel behavior of households: a case study of Montréal, Canada", International Journal of Sustainable Transportation, Vol. 7 No. 1, pp. 52-69.

Snyder, H. (2019), "Literature review as a research methodology: an overview and guidelines", Journal of Business Research, Vol. 104, pp. 333-339.

Snyder, H., Witell, L., Gustafsson, A., Fombelle, P. and Kristensson, P. (2016), "Identifying categories of service innovation: a review and synthesis of the literature", Journal of Business Research, Vol. 69 No. 7, pp. 2401-2408.

Sprei, F. and Ginnebaugh, D. (2018), "Unbundling cars to daily use and infrequent use vehicles-the potential role of car sharing", Energy Efficiency, Vol. 11 No. 6, pp. 1433-1447.

Steininger, K., Vogl, C. and Zettl, R. (1996), "Car-sharing organizations in mobility behavior", Transport Policy, Vol. 3 No. 4, pp. 177-185.

Teece, D.J. (2010), "Business models, business strategy and innovation”, Long Range Planning, Vol. 43 Nos 2-3, pp. 172-194.

Terama, E., Peltomaa, J., Rolim, C. and Baptista, P. (2018), "The contribution of car sharing to the sustainable mobility transition", Transfers, Vol. 8 No. 2, pp. 113-121.

Carsharing: a systematic literature review 
JOSM 32,6

Timmins, F. and McCabe, C. (2005), "How to conduct an effective literature search", Nursing Standard, Vol. 20 No. 11, pp. 41-47.

Tran, V., Zhao, S., Diop, E.B. and Song, W. (2019), "Travelers' acceptance of electric carsharing systems in developing countries: the case of China”, Sustainability, Vol. 11 No. 19, p. 5348.

Tranfield, D., Denyer, D. and Smart, P. (2003), "Towards a methodology for developing evidenceinformed management knowledge by means of systematic review", British Journal of Management, Vol. 14 No. 3, pp. 207-222.

Tuan Seik, F. (2000), "Vehicle ownership restraints and car sharing in Singapore", Habitat International, Vol. 24 No. 1, pp. 75-90.

Tyndall, J. (2017), "Where no cars go: free-floating carshare and inequality of access", International Journal of Sustainable Transportation, Vol. 11 No. 6, pp. 433-442.

Valor, C. (2020), "Anticipated emotions and resistance to innovations: the case of p2p car sharing", Environmental Innovation and Societal Transitions, Vol. 37, pp. 50-65.

Wang, N., Guo, J., Liu, X. and Liang, Y. (2020), "Electric vehicle car-sharing optimization relocation model combining user relocation and staff relocation", Transportation Letters, Article in press, pp. 1-12.

Weikl, S. and Bogenberger, K. (2013), "Relocation strategies and algorithms for free-floating car sharing systems", IEEE Intelligent Transportation Systems Magazine, Vol. 5 No. 4, pp. 100-111.

Weikl, S. and Bogenberger, K. (2015), "A practice-ready relocation model for free-floating carsharing systems with electric vehicles - mesoscopic approach and field trial results", Transportation Research Part C: Emerging Technologies, Vol. 57, pp. 206-223.

Wilhelms, M.P., Henkel, S. and Falk, T. (2017a), "To earn is not enough: a means-end analysis to uncover peer-providers' participation motives in peer-to-peer carsharing”, Technological Forecasting and Social Change, Vol. 125, pp. 38-47.

Wilhelms, M.P., Merfeld, K. and Henkel, S. (2017b), "Yours, mine, and ours: a user-centric analysis of opportunities and challenges in peer-to-peer asset sharing”, Business Horizons, Vol. 60 No. 6, pp. 771-781.

Witell, L., Snyder, H., Gustafsson, A., Fombelle, P. and Kristensson, P. (2016), "Defining service innovation: a review and synthesis", Journal of Business Research, Vol. 69 No. 8, pp. 2863-2872.

Wittkowski, K., Moeller, S. and Wirtz, J. (2013), "Firm's intentions to use nonownership services", Journal of Service Research, Vol. 16 No. 2, pp. 171-185.

Wu, C., Le Vine, S., Clark, M., Gifford, K. and Polak, J. (2020a), "Factors associated with round-trip carsharing frequency and driving-mileage impacts in London", International Journal of Sustainable Transportation, Vol. 14 No. 3, pp. 177-186.

Wu, C., Le Vine, S., Philips, S., Tang, W. and Polak, J. (2020b), "Free-floating carsharing users' willingness-to-pay/accept for logistics management mechanisms", Travel Behavior and Society, Vol. 21, pp. 154-166.

Zhang, Y. and Li, L. (2020), "Intention of Chinese college students to use carsharing: an application of the theory of planned behavior", Transportation Research Part F: Traffic Psychology and Behavior, Vol. 75, pp. 106-119.

Zhou, B. and Kockelman, K.M. (2011), "Opportunities for and impacts of carsharing: a survey of the Austin, Texas market", International Journal of Sustainable Transportation, Vol. 5 No. 3, pp. 135-152.

Zhou, F., Zheng, Z., Whitehead, J., Perrons, R., Page, L. and Washington, S. (2017), "Projected prevalence of car-sharing in four Asian-Pacific countries in 2030: what the experts think", Transportation Research Part C: Emerging Technologies, Vol. 84, pp. 158-177.

Zupic, I. and Čater, T. (2015), "Bibliometric methods in management and organization”, Organizational Research Methods, Vol. 18 No. 3, pp. 429-472. 
Appendix

Research stream

Transportation

Transportation Research Part D:

Transport and Environment

Transportation Research Part A:

Policy and Practice

Transport Policy

Transportation Research Part C:

Emerging Technologies

Transportation Research Part B:

Methodological

Transportation

Journal of Advanced Transportation Transportation Research Part E:

Logistics and Transportation Review

Transportation Letters

Travel Behaviour and Society

Transportation Science

International Journal of Transport

Economics

Transportation Quarterly

European Transport Research

Review

Transport Reviews

Traffic Engineering and Control

Journal of Public Transportation

Journal of Modern Transportation

European Transport-Trasporti

Europei

European Journal of Transport and

Infrastructure Research

Advances in Transportation Studies

Business and Management

International Journal of Automotive

Technology and Management

Business Strategy and The

Environment

Manufacturing and Service

Operations Management

Research in Transportation Business

and Management

Technological Forecasting and Social

Change

European Journal of Operational

Research
No. of

125

18

Environment and Energy

8 Sustainability (Switzerland)

17 International Journal of Sustainable

Transportation

15 Journal of Cleaner Production

13 Journal of Transport Geography

13 Environmental Innovation and Societal

Transitions

13 International Journal of Environmental

Research and Public Health

$7 \quad$ Sustainable Cities and Society

5 Energy Research \& Social Science

$4 \quad$ Energy Policy

4 Energy Efficiency

3 Environmental Science and Policy

2 Habitat International

2 Resources

2 Energy

No. of

papers

58

18

15

5

3

3

3

2

2

1

1

1

1

1

1

1 Sustainability: Science, Practice and Policy

1

Computer Science, Engineering and

Mathematics

1 IEEE Transactions on Intelligent

Transportation Systems

1 Journal of Intelligent Transportation

Systems: Technology, Planning, and

Operations

1 Discrete Applied Mathematics 2

$1 \quad$ Electronics (Switzerland) 2

Journal of Combinatorial Optimization

43 IEEE Transactions on Systems, Man, and

Cybernetics: Systems

4 Algorithms 1

4 Periodica Polytechnica Transportation 1

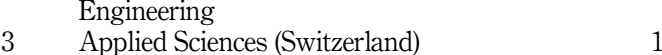

3 IEEE Intelligent Transportation Systems $\quad 1$

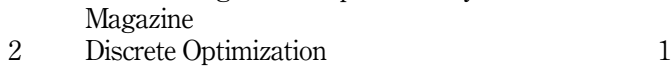

2 EPJ Data Science 1

(1)

(1)

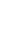

3

2

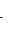

Carsharing:

a systematic literature review

Table A1.

Reviewed journals and 


\begin{tabular}{|c|c|c|c|}
\hline Research stream & $\begin{array}{l}\text { No. of } \\
\text { papers }\end{array}$ & Research stream & $\begin{array}{l}\text { No. of } \\
\text { papers }\end{array}$ \\
\hline Omega (United Kingdom) & 2 & Expert Systems with Applications & 1 \\
\hline Business Horizons & 1 & IEEE Access & 1 \\
\hline Cities & 1 & Transportation Research Record & 1 \\
\hline Decision Support Systems & 1 & Information Systems & 1 \\
\hline Computers and Operations Research & 1 & $\begin{array}{l}\text { Information Systems and e-Business } \\
\text { Management }\end{array}$ & 1 \\
\hline $\begin{array}{l}\text { EURO Journal on Transportation } \\
\text { and Logistics }\end{array}$ & 1 & $\begin{array}{l}\text { International Journal of Advanced Computer } \\
\text { Science and Applications }\end{array}$ & 1 \\
\hline Innovation & 1 & $\begin{array}{l}\text { International Journal of Geographical } \\
\text { Information Science }\end{array}$ & 1 \\
\hline $\begin{array}{l}\text { International Journal of Business and } \\
\text { Globalisation }\end{array}$ & 1 & $\begin{array}{l}\text { International Journal of Industrial } \\
\text { Engineering: Theory Applications and } \\
\text { Practice }\end{array}$ & 1 \\
\hline $\begin{array}{l}\text { International Journal of Information } \\
\text { and Decision Sciences }\end{array}$ & 1 & Soft Computing & 1 \\
\hline $\begin{array}{l}\text { International Journal of Quality and } \\
\text { Service Sciences }\end{array}$ & 1 & Journal of Intelligent and Fuzzy Systems & 1 \\
\hline $\begin{array}{l}\text { International Journal of Retail and } \\
\text { Distribution Management }\end{array}$ & 1 & Journal of Simulation & 1 \\
\hline Journal of Consumer Behaviour & 1 & Networks & 1 \\
\hline Journal of Consumer Research & 1 & Networks and Spatial Economics & 1 \\
\hline Journal of Ddecision Systems & 1 & Personal and Ubiquitous Computing & 1 \\
\hline $\begin{array}{l}\text { Journal of Science and Technology } \\
\text { Policy Management }\end{array}$ & 1 & Pervasive and Mobile Computing & 1 \\
\hline Journal of Service Research & 1 & Program & 1 \\
\hline MIS Quarterly Executive & 1 & $\begin{array}{l}\text { International Journal of Intelligent } \\
\text { Transportation Systems Research }\end{array}$ & 1 \\
\hline $\begin{array}{l}\text { IEEE Transactions on Engineering } \\
\text { Management }\end{array}$ & 1 & $\begin{array}{l}\text { Transportation Research Interdisciplinary } \\
\text { Perspectives }\end{array}$ & 1 \\
\hline $\begin{array}{l}\text { International Journal of Industrial } \\
\text { Organization }\end{array}$ & 1 & Transportmetrica B & 1 \\
\hline $\begin{array}{l}\text { International Journal of Research in } \\
\text { Marketing }\end{array}$ & 1 & & \\
\hline $\begin{array}{l}\text { International Journal of Services and } \\
\text { Operations Management }\end{array}$ & 1 & Urban Studies and other social sciences & 11 \\
\hline Journal of Marketing Management & 1 & $\begin{array}{l}\text { Transportation Research Part F: Traffic } \\
\text { Psychology and Behaviour }\end{array}$ & 3 \\
\hline Marketing Letters & 1 & $\begin{array}{l}\text { Theoretical and Empirical Researches in } \\
\text { Urban Management }\end{array}$ & 2 \\
\hline $\begin{array}{l}\text { Production and Operations } \\
\text { Management }\end{array}$ & 1 & Journal of American Studies & 1 \\
\hline Economics & 3 & $\begin{array}{l}\text { Urban Policy and Research } \\
\text { Continuum }\end{array}$ & $\begin{array}{l}1 \\
1\end{array}$ \\
\hline $\begin{array}{l}\text { Research in Transportation } \\
\text { Economics }\end{array}$ & 2 & Journal of Environmental Psychology & 1 \\
\hline Ecological Economics & 1 & $\begin{array}{l}\text { Journal of Urban Planning and Development } \\
\text { Planning Advisory Service Memo }\end{array}$ & $\begin{array}{l}1 \\
1\end{array}$ \\
\hline
\end{tabular}

Table A1.

\section{About the authors}

Brenda Nansubuga is a Ph.D. student in industrial marketing at Linköping University, Sweden, and her research interests include service-based business model innovation, with focus on the automotive sector.

Christian Kowalkowski is a Professor of Industrial Marketing at Linköping University and is affiliated with the Centre for Relationship Marketing and Service Management at Hanken School of 
Economics in Helsinki. Dr. Kowalkowski's research interests include service growth strategies, solutions marketing, service innovation and subscription business models. His work has been published in journals such as Journal of Service Research, Journal of Service Management, Journal of Service Theory and Practice, Service Industries Journal, Industrial Marketing Management and Journal of Business Research. He is the servitization editor for the Journal of Service Management, associate editor of the Journal of Services Marketing and advisory board member of Industrial Marketing Management. Christian Kowalkowski is the corresponding author and can be contacted at: christian.kowalkowski@ liu.se
Carsharing: a systematic literature review

For instructions on how to order reprints of this article, please visit our website: www.emeraldgrouppublishing.com/licensing/reprints.htm Or contact us for further details: permissions@emeraldinsight.com 